\title{
Conservation and Management of Isolated Pools in Temporary Rivers
}

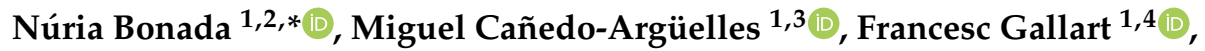 \\ Daniel von Schiller ${ }^{3}\left(\mathbb{D}\right.$, Pau Fortuño ${ }^{1,2} \mathbb{D}$, Jérôme Latron ${ }^{1,4}$, Pilar Llorens ${ }^{1,4}$, Cesc Múrria ${ }^{1,2} \mathbb{D}$, \\ Maria Soria $^{1,2}$, Dolors Vinyoles ${ }^{2}$ and Núria Cid ${ }^{1,5}$ D \\ 1 Freshwater Ecology, Hydrology and Management (FEHM) Research Group, UB-CSIC, Barcelona, \\ 08016 Catalonia, Spain; mcanedo.fem@gmail.com (M.C.-A.); francesc.gallart@idaea.csic.es (F.G.); \\ pfortuno@ub.edu (P.F.); jerome.latron@idaea.csic.es (J.L.); pilar.llorens@idaea.csic.es (P.L.); \\ cmurria@ub.edu (C.M.); mariasoriaextremera@gmail.com (M.S.); nuria.cid-puey@inrae.fr (N.C.) \\ 2 Departament de Biologia Evolutiva, Ecologia i Ciències Ambientals, Facultat de Biologia, Institut de Recerca \\ de la Biodiversitat (IRBio), Universitat de Barcelona (UB), Diagonal 643, Barcelona, 08016 Catalonia, Spain; \\ d.vinyoles@ub.edu \\ 3 Departament de Biologia Evolutiva, Ecologia i Ciències Ambientals, Facultat de Biologia, Institut de Recerca \\ de l'Aigua (IdRA), Universitat de Barcelona (UB), Diagonal 643, Barcelona, 08016 Catalonia, Spain; \\ d.vonschiller@ub.edu \\ 4 Institute of Environmental Assessment and Water Research (IDAEA), CSIC, Jordi Girona 18, Barcelona, \\ 08034 Catalonia, Spain \\ 5 INRAE, UR RiverLy, Centre de Lyon-Villeurbanne, Villeurbanne Cedex, 69000 Lyon, France \\ * Correspondence: bonada@ub.edu
}

Received: 7 August 2020; Accepted: 13 October 2020; Published: 15 October 2020

check for updates

\begin{abstract}
Temporary rivers are characterized by shifting habitats between flowing, isolated pools, and dry phases. Despite the fact that temporary rivers are currently receiving increasing attention by researchers and managers, the isolated pools phase has been largely disregarded. However, isolated pools in temporary rivers are transitional habitats of major ecological relevance as they support aquatic ecosystems during no-flow periods, and can act as refugees for maintaining local and regional freshwater biodiversity. Pool characteristics such as surface water permanence and size, presence of predators, local physicochemical conditions, time since disconnection from the river flow, or distance to other freshwater habitats challenge a comprehensive understanding of the ecology of these habitats, and challenge ecological quality assessments and conservation practices in temporary rivers. In this paper, we aim at providing a characterization of isolated pools from a hydrological, geomorphological, physicochemical, biogeochemical, and biological point of view as a framework to better conceptualize, conserve, and manage these habitats.
\end{abstract}

Keywords: intermittent rivers and ephemeral streams; hydrology; biogeochemistry; biodiversity

\section{Introduction}

Temporary rivers are fluvial ecosystems in which water stops flowing or dries out completely at any time of year. They may represent over $50 \%$ of the world's river network length [1], and future projections suggest their frequency will significantly increase in some regions as a result of climate and/or land cover change [2,3]. Despite their worldwide relevance and the numerous ecosystem services they provide $[4,5]$, temporary rivers have historically been neglected by researchers, managers, and society in general. In recent years, there have been significant advances in understanding their hydrology, geomorphology, biogeochemistry, ecology, management, and conservation [5-7]. However, 
many scientific and management gaps still remain related to methodological, geographical, disciplinary, and conceptual fields [8,9].

The changing hydrological conditions over time in temporary rivers allows the identification of six aquatic states [10] that differ in the proportion of the available habitats (Figure 1). The duration of each of these states depends on the local hydrogeological conditions (e.g., type of substrate and its permeability) and on the annual precipitation regime [11]. In practice, these aquatic states are often simplified in three phases (flowing, isolated pools, and dry) that represent lotic, lentic, and terrestrial habitats [12,13] or even in two periods (wet and dry) that inform the presence or absence of surface water [14] (Figure 1). Despite the importance of the isolated pools phase for hydrological and ecological processes, most studies focus on analysing changes between 'wet' and 'dry' periods with the isolated pools phase being included in the 'wet' or 'dry' period depending on the author scope. Moreover, those studies dealing with the isolated pools phase primarily consider biological and, to some extent, physicochemical features, whereas hydrological and geomorphological characterization has been largely overlooked.

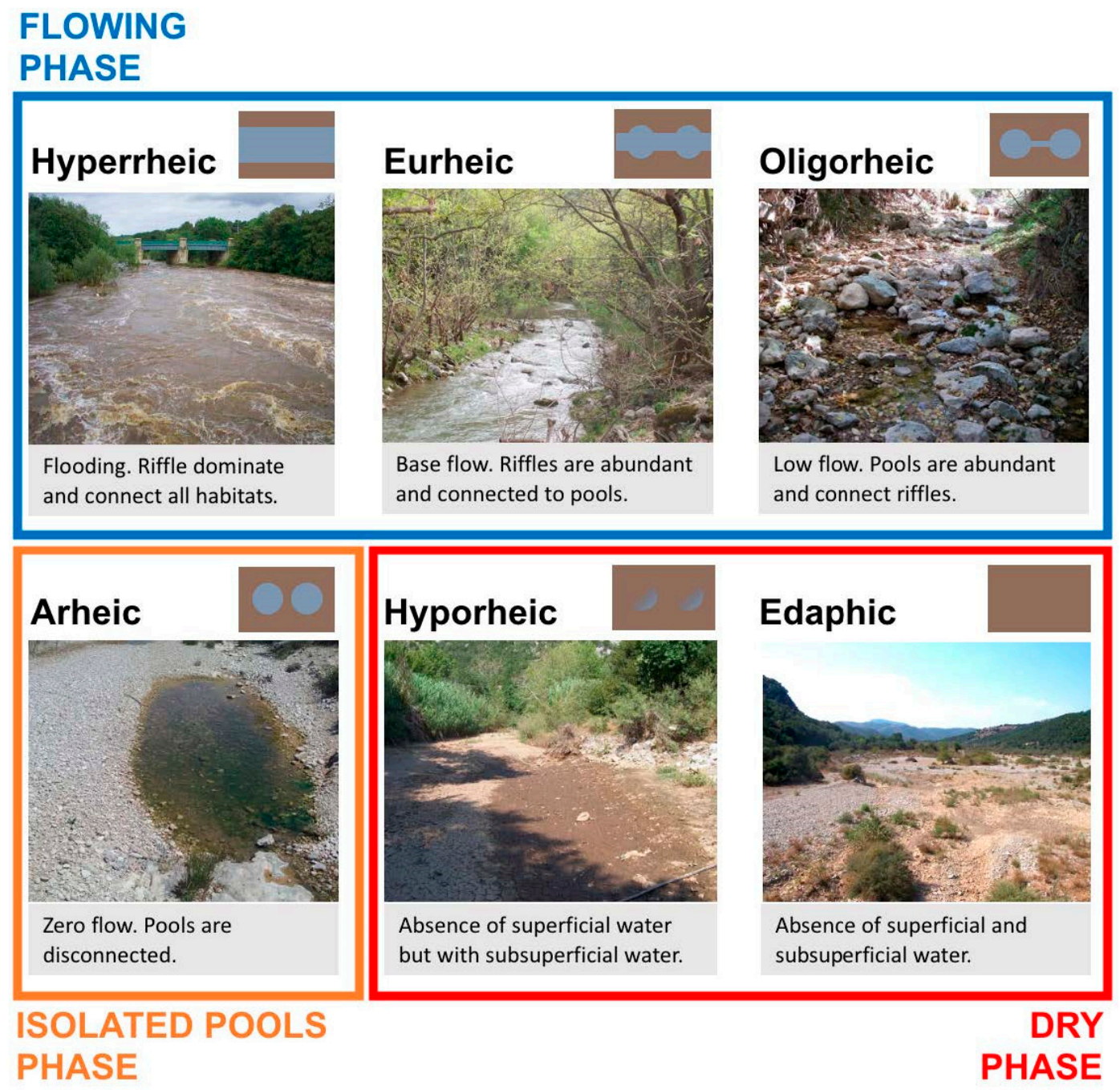

Figure 1. Aquatic states for temporary rivers according to Reference [10] and their simplification in phases [12,13]. Photo credits: MIRAGE and TRivers projects.

During the isolated pools phase, riverine isolated pools (IPs) can be commonly found at several locations along the river network. In some cases, these IPs can persist during many months [15], and act as transitional habitats between lotic habitats. In other cases, IPs dry up and are transitional 
habitats between lotic and terrestrial habitats. The relative frequencies of the three phases synthesize the hydrological controls on aquatic life and can be used to define the regime of the river reach [13].

IPs are most likely to be more frequent and last for shorter periods in arid than in humid climates [7]. Their presence or absence along a river network, as well as their temporal extent, depends on a combination of factors. First, similar to wetland filling [16], rainwater over IPs can also extend IPs duration or even create IPs in dry riverbeds (i.e., similar to rock or rain-fed pools [17]). Second, riparian vegetation can provide organic matter to IPs and reduce water evaporation by decreasing the surface temperature of IPs [18,19], but it can also increase their drying rate through transpiration [20,21]. Third, substrate permeability can influence IPs formation. In the absence of significant groundwater upwellings [22,23], high permeable substrates may prevent the formation of IPs, whereas bedrock can facilitate the formation of IPs similarly to rock pools [11,17]. Fourth, river geomorphology can also favour IPs, especially in narrow and deep gorges [24] or in rivers with riffle-pool sequences [25]. Finally, human alteration may also reduce the formation and duration of IPs through direct or indirect water withdrawals $[13,26]$. All this complexity increases the uncertainty to get a full understanding of IPs in temporary rivers but also provides challenges and opportunities for researchers and managers.

In this paper, we aim at providing a characterization of IPs in temporary rivers from a hydrological, geomorphological, physicochemical, biogeochemical, and a biological point of view as a framework to better conceptualize, conserve, and manage these habitats. Unlike upland temporary wetlands, ponds, rock pools, or vernal pools, IPs are hydrologically connected to lotic waters for certain periods of time. Some characteristics of these lentic ecosystems, however, could apply to IPs and have been used in this review when information on IPs was not available. This includes not only information from ponds, rock pools, or vernal pools but also from lentic ecosystems temporarily connected to lotic waters, such as temporary floodplain wetlands or surface-connected vernal pools [27-29].

\section{Hydrological Characterization of Isolated Pools}

Although rarely examined in conjunction with ecological studies, hydrology is the first factor controlling the ecology of IPs at both short-(i.e., seasonal) and long-(i.e., decadal) temporal scales [15,30]. At the short-term scale, seasonal hydrological changes control the timing and duration of the aquatic phases based on precipitation, evaporation, and subsurface flows. At the long-term scale, the interannual predictability of these seasonal hydrological changes (i.e., hydro-regime, [20]) constrains the adaptability of species and determines community composition to a particular river reach or even an IP [31].

Besides wetlands and ponds, there is a wide variety of pool-like habitats in freshwater ecosystems. Rock pools [17] and vernal pools [20,30,32] are temporary or semi-perennial water bodies not connected to river systems, but fed by shallow groundwater or by precipitation. In contrast, riverine pools (i.e., those belonging to the river system) are usually located in the principal or secondary channels of rivers $[15,31,33]$ or, as oxbows, in the alluvial plain without direct connection with the ordinary channels but usually fed by the alluvial water table $[34,35]$. The periods of surface flow connection in riverine pools are relatively frequent (i.e., monthly to seasonal), whereas they may be much less frequent (i.e., once every one to several years) in oxbows [35,36].

The hydro-regime of IPs is similar to that of rock and vernal pools except that the latter lack the recurrent transition between lotic and lentic conditions. Therefore, the hydro-regime of IPs depends on the hydroclimatic conditions of catchment and the river reach, but also on the location of IPs in relation to surface and subsurface water flows, and the local conditions (e.g., riparian vegetation). This results in three different types of IPs [15,31] (Figure 2). 


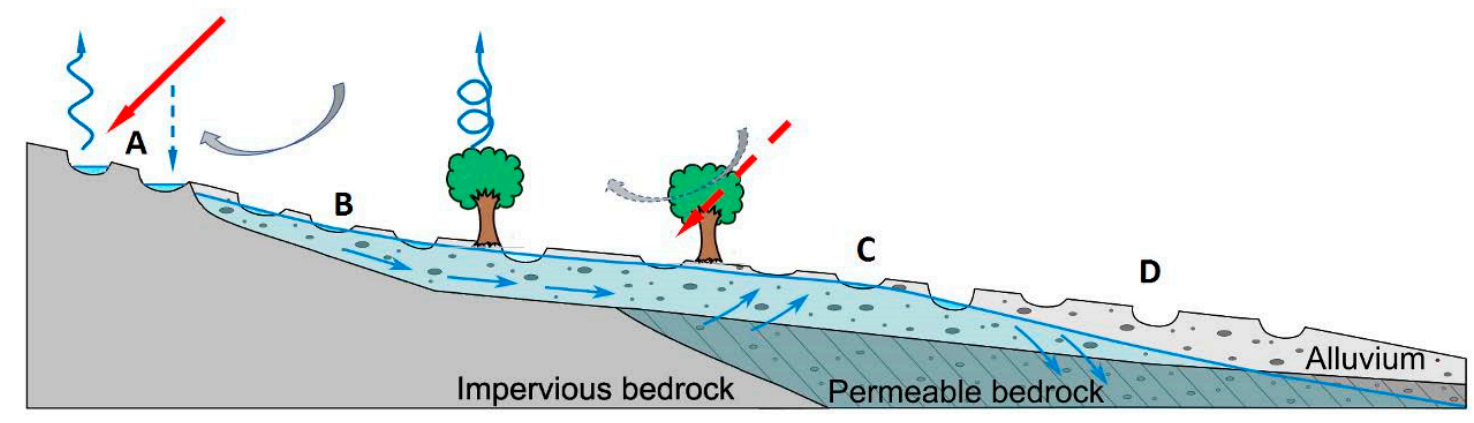

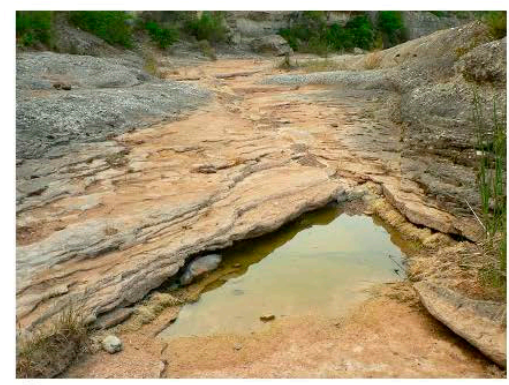

A

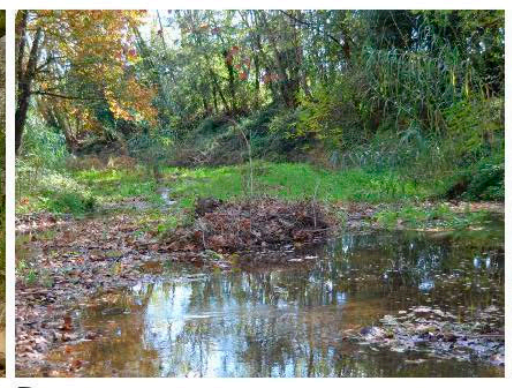

B

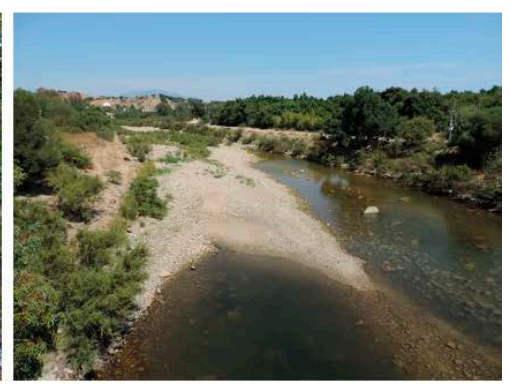

C-D

Figure 2. Schematic situation of isolated pools and their relationships with groundwater. (A): "perched" pools. (B): "through-flow" pools. (C): "groundwater gaining" pools. (D): "groundwater losing" pools. Blue arrows correspond to water (subsurface water, precipitation, evaporation, and transpiration). Red arrows correspond to direct or intercepted solar radiation. Grey arrows correspond to direct or intercepted wind. Modified from References [15,31]. Photo credits: FEHM-Lab.

Perched IPs (type A in Figure 2) are placed in the impervious bedrock or in impervious layers of the alluvial deposits without access to groundwater. These IPs are fed only by runoff or precipitation water and depleted only by evaporation from the water surface. Their hydro-regime is rarely affected by human water use, whereas the driving climatic conditions are more related to the evapotranspirative demand and the frequency of precipitation events rather than to their volume, given the limited capacity of the IPs. The geomorphology of this type of IPs is strongly controlled by the bedrock, although some alluvial deposits may appear in the bottom. This type of IP suffers the strongest changes in the physicochemical, biogeochemical, and biological characteristics after the disconnection of river flow, although the first changes may be alleviated by the input of rain water.

Through-flow IPs (Type B in Figure 2) exchange water with the alluvial aquifer. These IPs persist while the water reservoir is able to feed the evapotranspiration losses from the water surface and the riparian area as well as other longitudinal and lateral water leakages. The hydro-regime of these IPs is sensitive to the water use in the river catchment and channel, and the larger storage volume means that it is affected by both changes in the frequency and depth of precipitations. The occurrence of this type of IPs is strongly linked to the geomorphological processes in the channel, so they can change in size, shape, and location depending on the flow and sediment regimes. In large alluvial channels, particularly in those with braided patterns, the exchanges between surface and subsurface flow can allow the co-existence of the three phases in space (Figure 1). The exchanges with the alluvial waters can buffer changes in the physicochemical, biogeochemical, and biological characteristics after the disconnection of river flow. Nevertheless, if there is a sequence of this type of IPs in a river section, the changes in physicochemical properties of waters after the cessation of surface flow may increase downstream due to a cumulative effect [31].

Groundwater discharge IPs (Types C and D in Figure 2) are connected to the groundwater in the bedrock that emerges due to geological or topographical reasons [15]. The water balance depends on river flow, evapotranspiration rates, and exchanges with groundwater [37]. These IPs are usually the most persistent but also the most sensitive to environmental changes in the reach, catchment, and the 
recharge area of the aquifer. They can be "groundwater gaining" (type C) if IPs are connected to a shallow regional aquifer, or "groundwater losing" (type D) if IPs hang over a deeper regional aquifer. Rau et al. [38] provided a conceptual model of the regimes of this kind of IP, which depend on the response time of the aquifer to precipitation events. This type of IP shares most of the characteristics of the through-flow IPs, although their location usually depends on the geological setting that allows the emergence of groundwater [15]. Furthermore, the larger size of the groundwater store may increase its buffering effect on the volume and quality of their waters.

Obtaining hydrological information of IPs is often difficult, especially because gauging stations are usually not properly designed for measuring low flows [39], and also do not inform on the occurrence of IPs $[10,40]$. Rainfall-runoff models might be built for simulating the IP phase but, since they are usually constrained with flow records, the limitations of measured hydrographs are propagated to the simulated ones. In addition, many gauging stations are designed to interrupt subsurface flow through the alluvium in order to measure it as surface flow [41], and, therefore, low flows may be measured by these stations during the IPs phase. It is, therefore, recommended to inspect the design of the gauging stations because the relationships between gauge readings and real river state can be subject to several sources of errors [42].

Medium-term to long-term information on the occurrence and the hydro-regime of IPs can be obtained from alternative methods such as interviews with local citizens or water professionals as well as from the inspection of terrestrial and aerial photographs or remote sensing records $[13,40,43,44]$. Direct observations are usually made by professionals $[13,45,46]$. In France, for example, a national observatory to monitor low-flow levels called "Onde" (https://onde.eaufrance.fr/) was set up in 2012 and consists of 3300 stations spread all over the country. It visually assesses the river reach state between the three aquatic phases (i.e., flow, isolated pools, and dry) around the 25th of each summer month, from May to September. Citizen science apps, such as Crowdwater, RiuNet, and Stream Tracker, are also used for visually monitoring the hydrological condition of streams including the occurrence of IPs (CrowdWater.ch, riunet.net, streamtracker.org).

However, the most common method to monitor the hydro-regime of IPs is the use of small low-cost sensors. Indeed, field loggers with sensors such as electrical conductivity, water temperature, floating switches, or propellers may inform on the presence-absence of water and detect changes in hydrological conditions [47-51]. These sensors can be complemented with time-lapse cameras [51,52] so the local quantitative data recorded by the sensors is supplemented with the qualitative information captured by the photographs than can embrace larger areas.

Finally, when instrumentation is not possible, the time since disconnection from river flow could be estimated from the concentration of solutes and water isotopy. For example, as evaporation increases with time, the water of IPs becomes enriched with solutes (e.g., chloride) and heavy water isotopes (i.e., ${ }^{3} \mathrm{H}$ and $\left.{ }^{18} \mathrm{O},[33,37]\right)$. By investigating the concentration of conservative solutes or the isotopy of IP's water, it is possible to infer the relative amount of water evaporated since the pool has been disconnected, or the ratio between the evaporation and inflow rates if it is connected to the groundwater $[31,53]$. From here, it is possible to infer the time since disconnection. Nevertheless, these approaches may need the estimation of the water balance of the pools, particularly if the subsurface input or outputs are relevant $[37,38]$.

\section{Geomorphological Characterization of Isolated Pools}

Rivers are frequently characterized by alternating riffles and pools at the reach scale $[54,55]$. In comparison to riffles, and especially during low flows, pools are deeper, wider, with finer substrates, and with lower shear stress [56,57]. A large body of literature has tried to find regular patterns on the distance between pools but has struggled to define the limits of a pool [55]. The river flow regime might also modify the frequency of pools in the river channel. For example, high-magnitude and low frequency flows in headwaters can increase the presence of pools, shifting riffle-pool sequences to step-pool sequences [25]. In these cases, slope is important to determine the frequency and depth 
of pools in the river channel. In contrast, the decrease in slope and in particle size, together with the higher discharge and channel width, lead to larger pools in lowland rivers [58]. The presence of bedrock in the riverbed, as in perched IPs (Figure 2), can also modify locally the riffle-pool sequence by preventing infiltration [54].

In temporary rivers, riffles are the first areas to dry when flow decreases. Consequently, total water depth is reduced, but pools maintain residual depth depending on the riverbed morphology and the accumulated sediments [59] (Figure 3a). Some of these IPs, particularly perched IPs, can occur in the same places across multiple years. Others can appear and disappear in different places, which is a common pattern in braided gravel-bed rivers [60]. IPs can have different sizes (depth, area, volume), shapes, and substrate characteristics. All these attributes should be considered when characterising IPs from a geomorphological point-of-view because they determine IP duration [20]. In headwaters, IP size is usually smaller than in downstream reaches where high flows and wider alluvial channels are able to sustain larger IPs [25]. The shape of IPs is determined by the riverbed and the surrounding geomorphology (Figure 3). Over bedrock, the size and shape of the IP depends on the weathering properties of the rock [17]. Substrate characteristics can also be very variable. A common pattern is that, during IP formation, when flow decreases, sediments accumulate at the bottom and are partially mobilized with flow resumption [61] (Figure 3d).

Once IPs are formed, evaporation or infiltration change the geomorphological attributes over time (Figure 3). Residual depth and substrate heterogeneity change with time, depending on pool persistence and the amount of sediment as well as the presence of organic elements (e.g., submerged macrophytes, woody debris, or leaf litter), respectively [62,63]. Recent studies characterizing IPs in temporary rivers also included a characterization of the type of mineral substrates (i.e., bedrock, gravels, and fine sediments) and of the macrophyte species and coverage within the pool [64]. 

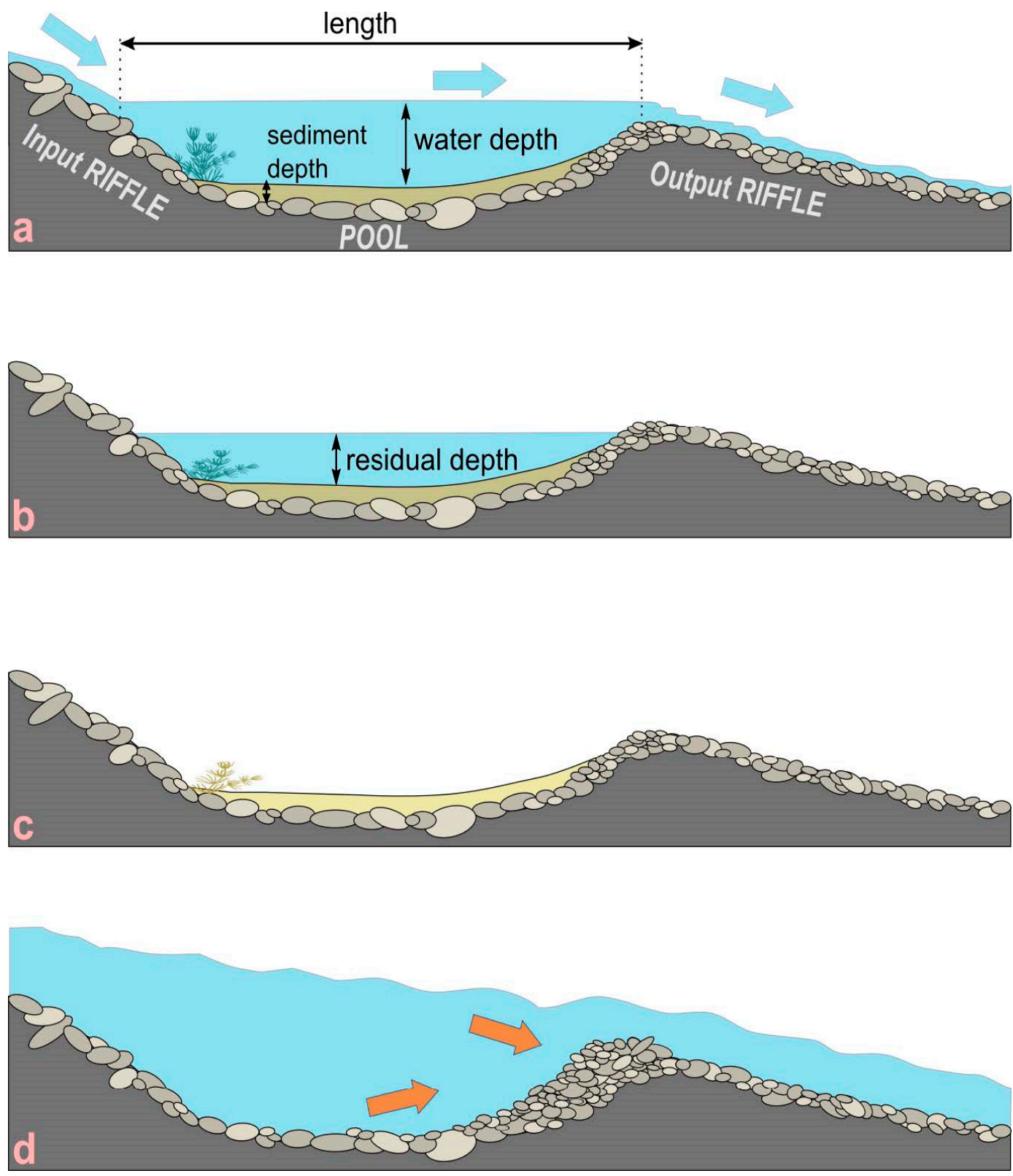

Figure 3. General geomorphological characteristics before (a), during (b), and after (c) the formation of an isolated pool, and with flow resumption (d). Blue arrows: water flow direction. Orange arrows: substrate mobilization direction. Modified from Reference [59].

\section{Physicochemical and Biogeochemical Characterization of Isolated Pools}

Stream fragmentation lead to profound shifts in the physicochemical and biogeochemical characteristics of surface and subsurface water in IPs $[65,66]$. The physicochemical quality of IPs usually changes dramatically after the disconnection of river flow, particularly in pools with limited or without exchanges with groundwater (Perched IPs in Figure 2 [67]). These changes increase the concentration of solutes such as chloride and nutrients such as nitrogen, phosphorus, and dissolved organic matter, which are attributed to both the concentration by water evaporation and the accumulation of leaves and other types of organic matter [31,68]. These physicochemical characteristics of IPs also determine the physicochemical composition of temporary rivers downstream after rewetting events, together with that provided by the upstream river and sediment runoff [65]. 
From a biogeochemical perspective, IPs can be viewed as accumulation sites, where advective transport and processing of material are significantly slowed down and retention is maximized [69]. The presence of surface water in IPs sustains higher biogeochemical processing rates compared to dry reaches with no surface water, but the rates and pathways at which materials are processed differ from those in flowing water. In other words, processing lengths become longer in IPs relative to flowing river reaches but shorter than in dry reaches [70].

The strong decline or complete lack of hydrological connectivity extremely reduces inputs of material from upstream and adjacent terrestrial ecosystems [71]. Some inputs of solutes via groundwater and/or hyporheic flow may remain [72] as well as direct inputs of particular organic matter from riparian vegetation [73]. But, overall, hydrological fragmentation into IPs leads to profound changes in redox conditions and increased relevance of in-stream biogeochemical processes relative to the flowing phase [66].

To some extent, IPs are governed by similar biogeochemical processes as ponds, rock, or vernal pools. As partly isolated systems, IPs, even those located in the same river section, may strongly differ in their biogeochemistry. These differences are largely driven by among-pool variations in abiotic (e.g., flow connectivity, groundwater exchange, light availability, organic matter inputs) and biotic (e.g., abundance of algae, plants, fish) factors. Absence of advection and low turbulence may lead to stratification in deeper pools, thereby disconnecting biogeochemical processes in the water column and sediments [74,75]. Accordingly, river fragmentation into IPs tends to increase the spatial heterogeneity of water chemistry along river sections [76-78].

In IPs, a lack of water renewal, low gas exchange, high water temperature, organic detritus accumulation, and high respiration rates commonly create a low oxygen and slightly acidic environment, where micro-aerophilic or anaerobic processes dominate $[65,66,79]$. Figure 4 illustrates such changes with data from an IP of a well-studied Mediterranean forest river (von Schiller et al. [66], unpublished data). If algae and macrophytes are abundant, diurnal dissolved oxygen and $\mathrm{pH}$ fluctuations may increase [80,81]. Consequently, marked temporal changes in metabolic pathways as well as in concentrations and forms of solutes occur during hydrological fragmentation. Some studies have investigated biogeochemical shifts in the surface water of IPs, but much less is known about changes in subsurface compartments $[72,82,83]$. Likewise, more information is available for the dynamics of organic matter and nutrients, especially nitrogen and phosphorus, than for other compounds such as metals $[65,66,79]$.

Low oxygen conditions in IPs causes significant changes in the composition and activity of microbial communities [84-86] and shifts biogeochemical processes toward reductive pathways, increasing the concentration of reduced solute forms in surface water [66,79]. For instance, denitrification is enhanced, and, thereby, reduces the concentration of nitrate in the water column [78]. Additional anaerobic metabolic pathways such as manganese and iron of sulphate reduction may be enhanced, leading to the decrease in concentration of oxidized forms of these elements [87]. In parallel, rapid mineralization of accumulated organic detritus increases the concentration of other reduced solute forms, such as ammonium [78,82]. Under low oxygen and $\mathrm{pH}$ conditions, desorption is also favoured, releasing adsorbed ions such as phosphate or ammonium from sediments to the water column [88].

Large quantities of allochthonous particulate organic matter can accumulate on the sediments of IPs [89-91]. On the one hand, despite this high availability, the rates of organic matter decomposition are slow in IPs compared to flowing water because of low microbial and shredder decomposing activity [92-94]. High rates of organic matter processing may only be maintained in subsurface sediments [83,95]. On the other hand, leaching and degradation of this organic detritus represents the major source of dissolved organic matter (DOM) in IPs of forested temporary rivers [96,97]. Autochthonous algal DOM sources may be more relevant in temporary rivers with less canopy cover because of lower leaf inputs and higher light availability [31,98]. 

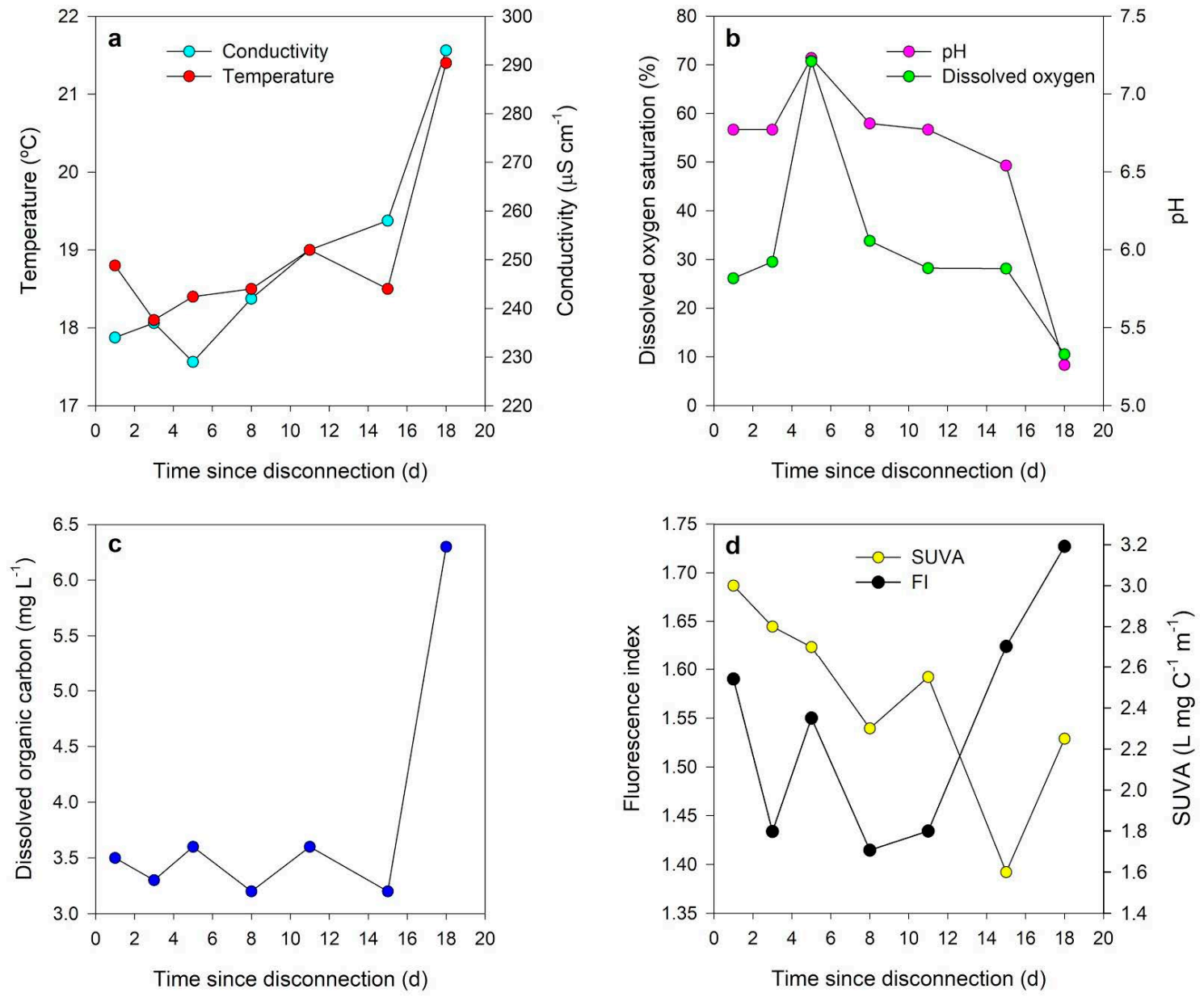

Figure 4. Temporal variation (i.e., time since disconnection in days), (d) of key physicochemical variables and dissolved organic matter (quantity and composition) in the surface water of an isolated pool (Fuirosos river, Catalonia, NE Spain). (a) Temperature and conductivity. (b) Dissolved oxygen saturation and $\mathrm{pH}$. (c) Concentration of dissolved organic carbon. (d) Two indexes of DOM composition: Fluorescence index and specific ultraviolet absorbance (SUVA). The largest shift in most variables occurred just before complete surface drying (day 18). A short flow pulse on day 4 reconnected the isolated pool for 3 days, causing changes in some of the shown variables.

Substantial shifts in the concentration and composition of DOM typically occur in the transition between flowing and IP phases [99-101]. Changes in DOM biodegradability can also occur [102]. Once IPs are formed, the concentration of DOM in the surface water tends to remain relatively stable over time $([68,99,100]$, see Figure 4). However, significant changes in DOM composition can be observed. In general, DOM becomes less aromatic and the relative abundance of low-molecular potentially labile DOM molecules increase with time since disconnection $([31,99,100]$, see Figure 4$)$. These DOM compositional changes indicate increased contribution of in-pool microbial and algal sources during hydrological fragmentation, especially in IPs disconnected from groundwater recharge [68]. Large quantities of available DOM fuels microbial respiration in IPs, leading to high concentrations of dissolved carbon dioxide [101,103]. Moreover, extremely low oxygen conditions at later stages of isolation may enhance methane production [103]. However, limited gas exchange and the lack of methane ebullition cause low emission fluxes for both gases [103].

\section{Biodiversity Characterization of Isolated Pools}

As temporary rivers move through phases (Figure 1), biological communities experience great changes ([104] for the microbial community, [105] for algae, [106] for macro-invertebrates, and [107] 
for fish). The main community shifts occur with the formation of the IPs, the loss of surface water, and flow resumption. IPs constitute a refuge for many species but constrains the presence of many others. Physicochemical shifts in IPs, especially in temperature, oxygen, $\mathrm{pH}$, and DOM, change microbial composition and function, with bacteria being more resistant than fungi $[104,108]$. The formation of IPs implies the disappearance of some species only found in lotic habitats (e.g., some macroinvertebrates and algae) and the progressive appearance of species that are found exclusively in lentic habitats [22,105]. Some lotic species may also remain and use IPs as refuges until life cycles are completed (e.g., some macroinvertebrates [109]), or use them to withstand the dry period (e.g., many Odonata or some fish $[22,110])$. Newly formed lentic habitats are colonized by taxa with overland dispersal traits from other nearby sites that may or may not be drying up $[22,106,111]$. These taxa include many species of Coleoptera and Hemiptera, which constitute the bulk of macro-invertebrate biodiversity in IPs [22,90]. Together with Odonata, the diversity of Coleoptera and Hemiptera $(\mathrm{OCH})$ in IPs surpass that of Ephemeroptera, Trichoptera, and Plecoptera (EPT), which are the most characteristic taxa in the flowing phase [11,111]. Species with low dispersal ability, such as many Gastropoda, can also be found in IPs, either because they got trapped when the river became fragmented, they arrived via passive dispersal through birds, or because they were reactivated from resistant forms remaining in the substrate if the pool was previously dry [112]. As for macro-invertebrates, communities of primary producers also shift toward a predominance of lentic species with an increase of bacterioplankton and benthic communities being progressively reduced [85]. In the case of fish, flow cessation and the subsequent formation of IPs represent a bottleneck period, but also a refuge where several species can coexist and survive until flow resumption occurs [107,113].

As time passes, the abiotic conditions of the IPs change and, with them, the biological communities therein. At this point, each IP acts as an island with local extinctions and colonization patterns. Eventually, if drying progresses, the aquatic habitat contracts and IPs are reduced in size and volume, affecting local communities due to changes in environmental conditions and/or to increased biotic interactions [22]. Local extinctions increase unless organisms go through resting stages or leave the IPs as terrestrial adults (i.e., many aquatic insects) or through passive dispersal via birds. As a result, dispersion has been favoured in organisms inhabiting lentic habitats [114]. With the complete drying of the IPs, many organisms die or enter into a resistance stage until flow resumption [115] (Figure 5).

The diversity and composition of biological communities in IPs depend on a wide variety of factors, acting at local and regional scales. Local factors include both abiotic and biotic characteristics of the IP, such as water physicochemistry, pool size, substrate heterogeneity, time since disconnection, pool duration, and biotic interactions. Regional factors include distance to other freshwater habitats that act as a source of organisms.

Local factors such as physicochemical conditions can become very harsh in some IPs, especially if IPs do not have water inputs for long periods (Section 4). Water temperature can be very high and oxygen conditions very low if, for example, there are high amounts of accumulated detritus [65]. Other IPs located in river reaches with no riparian cover can show high levels of primary production and reach high levels of anoxia during the night (Section 4). In such conditions, only a few species can survive. For example, larvae of macro-invertebrates having aerial respiration such as Culicidae or Nepidae can be abundant [11], together with some Chironomidae species with respiratory pigments enabling them to tolerate hypoxic conditions [116]. In the case of fish, despite some species in Africa and Australia having aerial respiration [107], most fish do not have specific adaptations and present critical thresholds for survival [117].

Pool size (i.e., area, depth, and volume) and substrate heterogeneity can also determine species richness and abundance [118]. Small pools typically host lower species richness than large pools. Volume is especially relevant for fish populations and communities, finding higher species richness [119,120] and higher fish persistence [117] in IPs with larger volumes. At the same time, larger IPs usually have higher substrate heterogeneity, influencing IPs biodiversity [121]. A study on macroinvertebrate communities from temporary rivers with IPs found that the microhabitat structure 
was the most important factor influencing community composition [122]. In general, a higher diversity of substrate within a large IP can provide higher aquatic diversity.
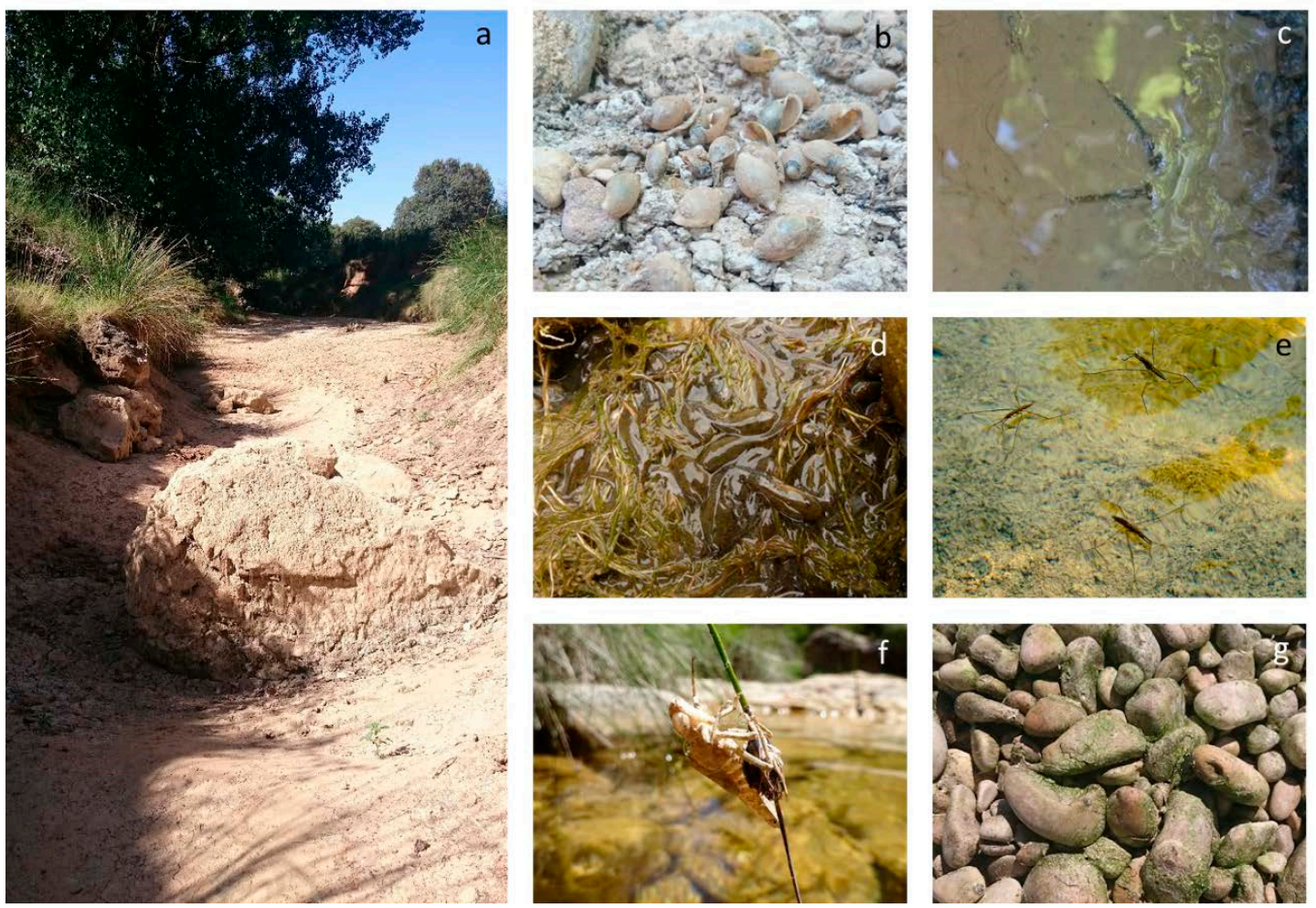

Figure 5. A dry isolated pool in the Guadazaón River (Júcar river basin, Spain) (a) and effects on the aquatic organisms. Some of them, such as molluscs (b), aquatic insects (c), or amphibians (d) without life cycles synchronized with drying are trapped in dry river beds and eventually die. Others, such as many heteropterans (e), are able to fly away and look for other aquatic refuges. Several species also have their life cycles synchronized and emerge before the IP dries up (f) (a larvae of Odonata) or stay in dry river beds as resistant forms until flow resumption (g) (benthic algae) [115]. Photo credits: N. Cid $(\mathbf{a}-\mathbf{c}, \mathbf{f}, \mathbf{g})$ and N. Bonada $(\mathbf{d}, \mathbf{e})$.

As in rock pools or temporary ponds, time since disconnection and pool duration may also determine biological communities in IPs [116,118]. Pool duration is also relevant for populations in IPs as it can correlate with fitness (e.g., in amphibians [123]). The higher community variability observed in IPs is a consequence of the change of abiotic and biotic interactions with time [22]. The newly formed IPs constitute new habitats for secondary succession processes. With the loss of lotic habitats biomass, diversity, and productivity decreases but increases again with time with the arrival of new colonisers and a more stability of the ecosystem [124]. Accordingly, communities change with time and modelling these changes could be crucial to develop future metrics to assess the biological quality of IPs (see Section 6).

Once IPs are formed, biotic interactions increase $[125,126]$. Fish, for example, have a significant top-down effect on macroinvertebrates in IPs changing their density and assemblage [127]. Similarly, many studies focused on rock pools show that the presence of predators is a key factor that determines richness and community composition of IPs. However, competitive interactions and parasitism can also play an important role $[17,126]$. In IPs undergoing drying and strong habitat contraction, fish may be extirpated due to physiological stress or to predation by terrestrial animals, resulting in shorter food chain length [125]. Typically, the longer the time since disconnection, the harsher the physicochemical conditions, the smaller the pool size, and the stronger the effect of biotic interactions on local communities [125]. 
In general, local abiotic and biotic factors will interact with regional processes driven by the hydrological regime. For example, in an experiment conducted with fish metacommunities, the different local characteristics of IPs, together with flow connectivity and dispersal, contributed to shape local community composition [128]. In line with this observation, Reference [129] found that the effects of the hydro-regime of IPs were less important for macroinvertebrates with aerial dispersal than for fully aquatic organisms.

The distance of IPs to other freshwater habitats determines their biodiversity through colonization/extinction (i.e., source/sink) dynamics [130]. If the IPs are close to other freshwater habitats, species with high dispersal abilities might sustain populations under sub-optimal environmental conditions through an immigration of individuals coming from nearby habitats (i.e., mass effects, [131]). In these conditions, stochasticity and priority effects prevail, at least at the early stages of hydrological disconnection. Nonetheless, species can be further selected by niche filtering as the IPs dry [132]. On the contrary, when IPs are far away from other freshwater habitats, niche filtering becomes more important and species adapted to the prevailing environmental conditions dominate (i.e., species sorting, [133]). The effect of habitat connectivity on aquatic biodiversity also depends on the dispersal strategy of the organisms. For example, for organisms such as fish that disperse exclusively by water, the timing and duration of the connection of IPs with the river flow is critical for their survival [120] whereas, for species that are able to disperse overland (e.g., by flying), the availability of nearby freshwater habitats can be more important to explain species composition of IPs [134]. Finally, biotic interactions could also be affected by the distance of IPs to other freshwater habitats. For example, weak competitors might be more abundant in remote IPs, since they are not much affected by the immigration of stronger competitors and predators (i.e., mass effects).

All the previously mentioned local and regional factors result in high variability of populations and communities found in IPs even when they are located close in space [22,135] (Figure 6). These Ips, thus, significantly contribute to the higher beta-diversity values reported in temporary rivers in comparison to perennial ones considering both spatial and temporal beta diversity [136,137], and they can harbour complementary sets of species that contribute to gamma (i.e., regional) diversity [138] (Figure 6). This has already been reported for temporary ponds and wetlands, where unique biodiversity adapted to living under harsh environmental conditions can be found [139-141].
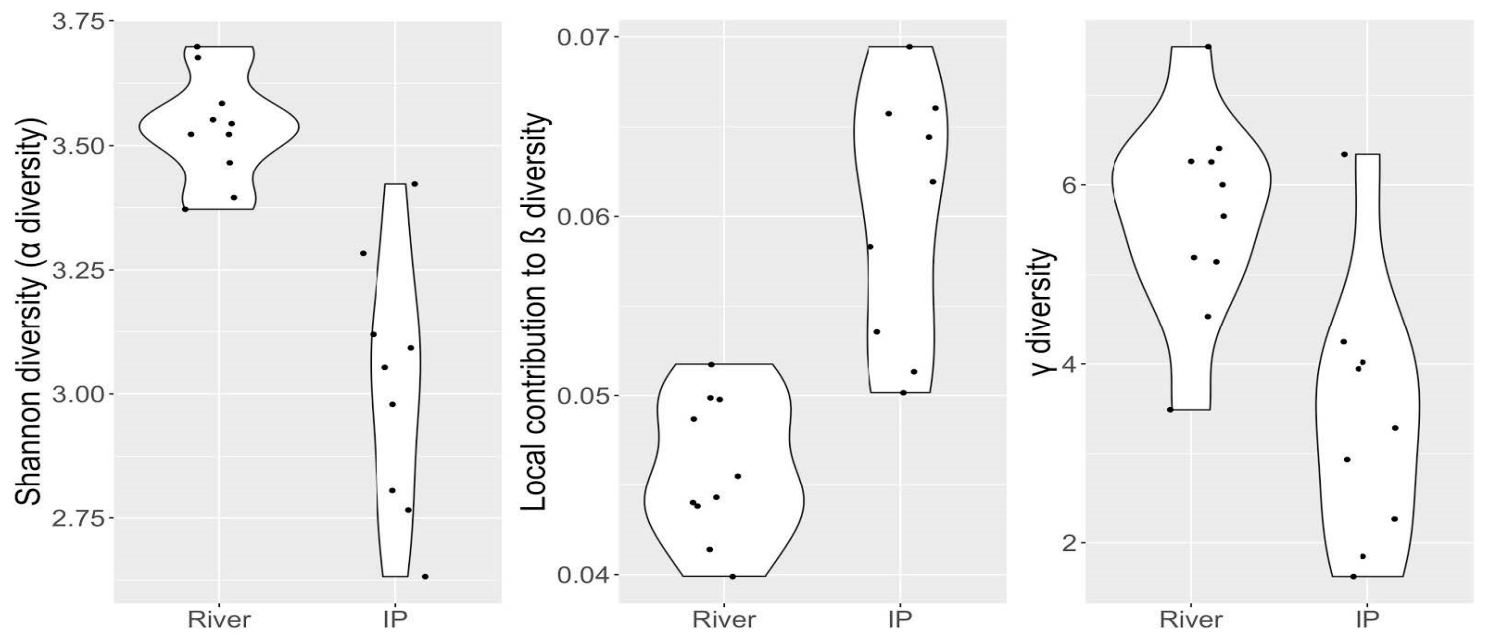

Figure 6. Comparison of alpha (i.e., Shannon diversity), beta (local contribution to beta diversity) and gamma diversity between independent perennial rivers (left) and isolated pools ((right), IPs) from California sampled simultaneously (data from Reference [22]). 


\section{Conservation of Isolated Pools: Current Management Needs and Future Perspectives}

Temporary rivers provide numerous and unique ecosystem services that should be valued by the society $[4,5,139]$. In particular, services provided by IPs are similar to those provided during the flowing phase with the exception of those that imply water quality issues or the presence of flowing waters [4]. For example, swimming in IPs can be less attractive if water quality decreases with time [5], or the loss of surface flow can reduce toxic sequestration [4]. Despite all these ecosystem services, however, the social perception of IPs and their conservation value is much lower than that of the flowing phase or perennial rivers, and partly higher than that of dry riverbeds [142].

From a conservation point of view, IPs are key refuges for maintaining viable populations of aquatic taxa during the dry season, which can recolonize the river network upon flow resumption [111,143]. Moreover, IPs can serve as stepping stones for many organisms. For example, adults of Heteroptera or Coleoptera can use IPs as resting areas when moving through the landscape. However, species inhabiting IPs appear to be highly vulnerable, especially if these IPs eventually dry up or are isolated from other aquatic refuges. In addition, IPs are highly vulnerable to human pressures because of their size and their low social value. Even the existence of IPs on alluvial river channels (Types B, C, and $\mathrm{D}$ in Figure 2) may be threatened in highly regulated rivers. The regulated medium and low flows cause the deposition of sediments at the bottom of pools and lead to their clogging unless high flows renovate the pool-riffle sequence (step d in Figure 3).

The ecological dynamics of IPs are quite similar to those of temporary wetlands and ponds. The importance of these ecosystems to biodiversity [144-146] and their drastic global decline [144] has led to great development of conservation and management actions that could be adapted to IPs. For example, studies in Morocco reported a loss of $63 \%$ of species in temporary wetlands [147]. As happens with IPs, temporary wetlands and ponds have been often neglected in water quality and ecological monitoring programmes. For example, small wetlands and ponds are excluded from the European Water Framework Directive because of being smaller than the stated size threshold of 50 ha [148]. Overall, as it happens with small wetlands and ponds, the need for conserving and assessing IPs needs to be recognized by managers and policy-makers so they are adequately represented in monitoring networks, statutory networks of protected areas, and legislation $[149,150]$. For example, IPs could be included as a priority in the European Habitats Directive, as it has been done with Mediterranean temporary ponds $[150,151]$.

A preliminary step for the conservation of IPs would be to develop a detailed inventory and characterize their biodiversity. In that sense, they could be included as a particular case of "small water bodies" (sensu [149]) present in large rivers. Conservation planning of IPs should also prioritize those IPs that contribute the most to maintain regional aquatic biodiversity, for instance, when using systematic conservation approaches [152]. This prioritization should incorporate those IPs acting as refugia [143] and as stepping stones for species dispersal (see above). Local specific management actions to mitigate human stressors should be implemented for the conservation of IPs because their small size and low dilution capacity make them especially vulnerable to chemical pollution and nutrient enrichment [65]. Thus, management actions should target water quality (e.g., prevent livestock accessing IPs by restoring natural barriers or by fencing). The metacommunity framework could be important to decide if conservation actions should improve local conditions (i.e., niche filtering) or favour landscape connectivity (i.e., dispersal) by installing artificial IPs (Cid et al., under review). All these conservation actions considering IPs as unique aquatic habitats or as part of the river network are also relevant in order to promote their ecosystem functions and services.

All bio-assessment methods have been originally developed for perennial rivers and their performance in temporary rivers is weak [153]. Temporary rivers have been neglected in the legislation of most countries, even those with a high occurrence of these fluvial ecosystems [154,155]. More recently, water agencies have recognized the need to consider these ecosystems in water management plans, but adapted methods are still under development and numerous uncertainties have arisen $[5,156]$. These methodologies have suggested using alternative metrics during the flowing phase [153], using 
terrestrial organisms-based metrics during the dry phase [156], adapting the boundary quality classes or the reference conditions for temporary rivers [156], or considering the metacommunity approach in the bioassessment [157]. However, no information is available to assess the ecological status of temporary rivers during the IPs phase, despite these habitats comprising a high proportion of water bodies (sensu European Water Framework Directive) in some areas. For example, in the Catalan water district (NE Spain), out of the 248 water bodies, 31 have IPs for at least one month. In addition, a reliable evaluation of the ecological status of IPs is needed because (1) of their importance in terms of biodiversity conservation, especially for some organisms such as fish [107], (2) of their role as key refuges to ensure the recolonization of temporary rivers during the flow resumption [111,158], (3) their occurrence is expected to increase, especially in those regions where temporary rivers will be more frequent [2,3], and (4) physicochemical characteristics and biological communities change in a way that makes it difficult to disentangle the natural effects of IPs from human activities affecting them. Thus, traditional methods developed for perennial rivers do not apply $[65,153]$.

According to the current water legislations, such as the European Water Framework Directive or the US Clean Water Act, methods to assess the ecological status of river ecosystems should rely on physicochemical, hydro-morphological, and biological indicators. New methods for assessing temporary rivers during the IPs phase should, therefore, consider these aspects and, in some cases, metrics used for wetlands and ponds could be applied. For example, for physicochemical indicators, phosphorus bioavailability in the sediment is a good measure of eutrophication $[159,160]$, but it is also important to consider that nutrients can be significantly high in IPs even in the absence of human impacts because of water evaporation $[31,68]$. Similarly, despite being considered a key physicochemical indicator, dissolved oxygen concentration can experience high diel variability and even deplete to anoxia, which can mobilize nutrients from sediments and decrease the chemical quality of the IP [65]. Evaporation of the IPs also controls salinity, especially in perched IPs not connected to groundwater $[65,161]$. Therefore, if the target is to assess the general physicochemical quality of IPs, care is needed because alterations of these physicochemical indicators do not necessarily mean the presence of human impact.

Hydro-morphological indicators in IPs should consider hydrological alterations of the IP as well as the alterations in the surrounding riparian habitat. Human withdrawals can increase the occurrence of IPs in former perennial rivers and/or accelerate their drying. In some particular cases, such as the perennialization of temporary rivers by effluents from wastewater treatment plants [162], natural IPs can disappear. Identifying human-driven hydrological alterations in temporary rivers is a key issue for their current and future management and conservation [13]. Some approaches have been developed to assess the hydrological status of rivers (e.g., [163]) with few of them even considering the IPs phase of temporary rivers [13]. The assessment of the hydrological status of IPs should precede that of the ecological status. If the presence of the IP is a consequence of human withdrawals, its ecological status should be assessed by following the methods originally developed for that river. If IPs are not hydrologically impacted, the lack of connectivity should not be considered as a human impact because it is a property of IPs. In these cases, the hydromorphological quality should exclusively rely on the riparian habitat conditions, including, for example, adaptations of riparian quality indices to temporary rivers [164] or adaptations of current hydro-morphological indices developed in wetlands [165].

There are no metrics designed to assess the biological quality of IPs. However, among the different metrics that have been developed for lentic ecosystems (reviewed by Reference [148]), several could be directly used in IPs (e.g., amphibian richness and abundance, taxa richness of lentic invertebrates, and the abundance and community composition of aquatic macrophytes). Other metrics used in lentic ecosystems would likely require adaptation. For example, whereas plankton communities have been used for assessing the ecological status of ponds and wetlands $[148,166]$, there is almost no information available on the plankton dynamics of IPs. Regarding zooplankton, the hatching success of egg banks has been proposed as an indicator of the conservation status of wetlands [167] and it could be explored 
for IPs if information is available. Alternatively, metrics for assessing IPs could consider the same type of organisms as in rivers (i.e., diatoms, macrophytes, macroinvertebrates, and fish).

Regardless of the metrics and the organisms used, reference conditions in IPs should be established. Reference conditions for IPs should be dynamic given that communities are expected to change with time since disconnection and should consider all heterogeneity elements that influence biodiversity of IPs (i.e., the abiotic and biotic factors mentioned above). As for temporary rivers, metrics based on functional traits may provide a better evaluation of the biological quality than the traditional taxonomic metrics [153] and should slowly be incorporated in routine bioassessment protocols. Finally, the use of metabarcoding techniques on water and sediment samples (environmental DNA, eDNA) could be highly relevant in IPs $[168,169]$ and specific eDNA applications have already been suggested for ponds [170]. The incorporation of these techniques would (1) allow a less invasive sampling as no organisms are collected, and (2) provide the information at species level for those species included in reference DNA barcode libraries. This can be vital for IPs conservation, especially for those having a small size and/or representing key dry season refuge for obligate aquatic fauna such as fish. In this sense, metabarcoding could help in the assessment of biodiversity of large IPs with difficult visibility or accessibility (e.g., large waterholes) where fish are difficult to catch/sample and, thereby, contribute to identifying dry season fish refuges [171,172].

IPs are shifting temporary habitats of high ecological relevance that have been largely ignored by managers and researchers, even those working on temporary rivers. Since global expectations predict an increase of temporary rivers in many areas of the world [2,3], most likely the frequency of IPs will also increase. Therefore, there is an urgent need to better characterise these ecosystems and address appropriate conservation and management actions to maintain local and regional biodiversity, their unique ecological processes, and the ecosystem services they provide.

Author Contributions: N.B., M.C.-A., F.G. and N.C. conceived the ideas of this manuscript and significantly contributed to the writing together with D.v.S., P.F. contributed to the figures. P.F., J.L., P.L., C.M., M.S. and D.V. contributed to the drafts. All authors approved the submission. All authors have read and agreed to the published version of the manuscript.

Funding: This paper was supported by the by the MECODISPER project (CTM2017-89295-P) funded by the Spanish Ministerio de Economía, Industria y Competitividad (MINECO)-Agencia Estatal de Investigación (AEI) and co-funded by the European Regional Development Fund (ERDF), the TRivers-P project (ACA210/18/00022) funded by the Catalan Water Agency, and the RHYSOTTO project (PID2019-106583RB-I00) funded by the Spanish Ministerio de Ciencia e Innovación. N.B. and D.v.S. are Serra Húnter Fellows. N.C. was supported by the French research program Make Our Planet Great Again (MOPGA). D.v.S. was supported by the project PURIFY (ACRP10-PURIFY-KR17AC0K13643) funded by the Austrian Government. The FEHM (Freshwater Ecology, Hydrology and Management) research group is funded by the "Agència de Gestió d'Ajuts Universitaris i de Recerca" (AGAUR) at the "Generalitat de Catalunya" (2017SGR1643).

Acknowledgments: We are very grateful to Narcís Prat for his support and encouraging ideas.

Conflicts of Interest: The authors declare no conflict of interest.

\section{References}

1. Datry, T.; Larned, S.T.; Tockner, K. Intermittent rivers: A challenge for freshwater ecology. BioScience 2014, 64, 229-235. [CrossRef]

2. Döll, P.; Schmied, H.M. How is the impact of climate change on river flow. Environ. Res. Lett. 2012, 7, 014037. [CrossRef]

3. Pumo, D.; Caracciolo, D.; Viola, F.; Noto, L.V. Climate change effects on the hydrological regime of small non-perennial river basins. Sci. Total Environ. 2016, 542, 76-92. [CrossRef] [PubMed]

4. Datry, T.; Boulton, A.J.; Bonada, N.; Fritz, K.; Leigh, C.; Sauquet, E.; Tockner, K.; Hugueny, B.; Dahm, C.N. Flow intermittence and ecosystem services in rivers of the Anthropocene. J. Appl. Ecol. 2018, 55, 353-364. [CrossRef]

5. Magand, C.; Alves, M.H.; Calleja, E.; Datry, T.; Dörflinger, G.; England, J.; Gallart, F.; Gómez, R.; Jorda-Capdevila, D.; Marti, E.; et al. Intermittent Rivers and Ephemeral Streams: What Water Managers 
Need to Know; Technical Report-Cost ACTION CA; European Cooperation in Science and Technology: Brussels, Belgium, 2020. [CrossRef]

6. Leigh, C.; Boulton, A.J.; Courtwright, J.L.; Fritz, K.; May, C.L.; Walker, R.H.; Datry, T. Ecological research and management of intermittent rivers: An historical review and future directions. Freshw. Biol. 2016, 61, 1181-1199. [CrossRef]

7. Datry, T.; Bonada, N.; Boulton, A.J. General introduction. In Intermittent Rivers and Ephemeral Streams: Ecology and Management; Datry, T., Bonada, N., Boulton, A.J., Eds.; Elsevier, Inc.: Cambridge, MA, USA, 2017; pp. 1-20. [CrossRef]

8. Datry, T.; Bonada, N.; Boulton, A.J. Conclusions: Recent advances and future prospects in the ecology and management of intermittent rivers and ephemeral streams. In Intermittent Rivers and Ephemeral Streams: Ecology and Management; Datry, T., Bonada, N., Boulton, A.J., Eds.; Elsevier, Inc.: Cambridge, MA, USA, 2017; pp. 563-584. [CrossRef]

9. Skoulikidis, N.T.; Sabater, S.; Datry, T.; Morais, M.M.; Buffagni, A.; Dörflinger, G.; Zogaris, S.; Sánchez-Montoya, M.M.; Bonada, N.; Kelogianni, E.; et al. Non-perennial Mediterranean rivers in Europe: Status, pressures, and challengers for research and management. Sci. Total Environ. 2017, 577, 1-18. [CrossRef]

10. Gallart, F.; Prat, N.; García-Roger, E.M.; Latron, J.; Rieradevall, M.; Llorens, P.; Barberá, G.G.; Brito, D.; De Girolamo, A.M.; Lo Porto, A.; et al. A novel approach to analysing the regimes of temporary streams in relation to their controls on the composition and structure of aquatic biota. Hydrol. Earth Syst. Sci. 2012, 16, 3165-3182. [CrossRef]

11. Bonada, N.; Rieradevall, M.; Prat, N. Macroinvertebrate community structure and biological traits related to flow permanence in a Mediterranean river network. Hydrobiologia 2007, 589, 91-106. [CrossRef]

12. Datry, T.; Pella, H.; Leigh, C.; Bonada, N.; Hugueny, B. A landscape approach to advance intermittent river ecology. Freshw. Biol. 2016, 61, 1200-1213. [CrossRef]

13. Gallart, F.; Cid, N.; Latron, J.; Llorens, P.; Bonada, N.; Jeuffroy, J.; Jiménez-Argudo, S.M.; Vega, R.M.; Solà, C.; Soria, M.; et al. TREHS: An open-access software tool for investigating and evaluating temporary river regimes as a first step for their ecological status assessment. Sci. Total Environ. 2017, 607, 519-540. [CrossRef]

14. Baldwin, D.S.; Mitchell, A.M. The effects of drying and re-flooding on the sediment and soil nutrient dynamics of lowland river-floodplain systems: A synthesis. Regul. Rivers Res. Manag. 2000, 16, 457-467. [CrossRef]

15. Bourke, S.A.; Shanafield, M.; Hedley, P.; Dogramaci, S. A hydrological framework for persistent river pools in semi-arid environments. Hydrol. Earth Syst. Sci. Discuss. 2020. [CrossRef]

16. Roshier, D.A.; Whetton, P.H.; Allan, R.J.; Robertson, A.I. Distribution and persistence of temporary wetland habitats in arid Australia in relation to climate. Austral Ecol. 2001, 26, 371-384. [CrossRef]

17. Jocque, M.; Vanschoenwinkel, B.; Brendonck, L. Freshwater rock pools: A review of habitat characteristics, faunal diversity and conservation value. Freshw. Biol. 2010, 55, 1587-1602. [CrossRef]

18. Holzapfel, G.; Weihs, P.; Rauch, H.P. Use of the Shade-a-lator 6.2 model to assess the shading potential of riparian purple willow (Salix purpurea) coppices on small to medium sized rivers. Ecol. Eng. 2013, 61, 697-705. [CrossRef]

19. Trimmel, H.; Weihs, P.; Leidinger, D.; Formayer, H.; Kalny, G.; Melcher, A. Can riparian vegetation shade mitigate the expected rise in stream temperatures due to climate change during heat waves in a human-impacted pre-alpine river? Hydrol. Earth Sysy. Sci. 2018, 22, 437-461. [CrossRef]

20. Leibowitz, S.G.; Brooks, R.T. Hydrology and landscape connectivity of vernal pools. In Science and Conservation of Vernal Pools in Northeastern North America; Calhouh, A.J.K., deMaynadier, P.G., Eds.; CRC Press: Boca Raton, FL, USA, 2008; pp. 31-53.

21. Lupon, A.; Bernal, S.; Poblador, S.; Martí, E.; Sabater, F. The influence of riparian evapotranspiration on stream hydrology and nitrogen retention in a subhumid Mediterranean catchment. Hydrol. Earth Syst. Sci. 2016, 20, 3831-3842. [CrossRef]

22. Bonada, N.; Rieradevall, M.; Prat, N.; Resh, V.H. Benthic macroinvertebrate assemblages and macrohabitat connectivity in Mediterranean-climate streams of northern California. J. N. Am. Benthol. Soc. 2006, 25, 32-43. [CrossRef] 
23. Boulton, A.J.; Rolls, R.J.; Jaeger, K.L.; Datry, T. Hydrological connectivity in intermittent rivers and ephemeral streams. In Intermittent Rivers and Ephemeral Streams: Ecology and Management; Datry, T., Bonada, N., Boulton, A.J., Eds.; Elsevier, Inc: Cambridge, MA, USA, 2017; pp. 79-108. [CrossRef]

24. Jaeger, K.L.; Sutfin, N.A.; Tooth, S.; Michaelides, K.; Singer, M. Geomorphology and sediment regimes of intermittent rivers and ephemeral streams. 2017. In Intermittent Rivers and Ephemeral Streams: Ecology and Management; Datry, T., Bonada, N., Boulton, A.J., Eds.; Elsevier, Inc.: Cambridge, MA, USA, 2017; pp. 21-49. [CrossRef]

25. Chin, A. The morphologic structure of step-pools in mountain streams. Geomorphology 1999, 27, $191-204$. [CrossRef]

26. Chiu, M.-C.; Leigh, C.; Mazor, R.; Cid, N.; Resh, V. Anthropogenic threats to intermittent rivers and ephemeral streams. In Intermittent Rivers and Ephemeral Streams: Ecology and Management; Datry, T., Bonada, N., Boulton, A.J., Eds.; Elsevier, Inc.: Cambridge, MA, USA, 2017; pp. 433-454. [CrossRef]

27. Bourgeau-Chavez, L.L.; Lee, Y.M.; Battaglia, M.; Endres, S.L.; Laubach, Z.M.; Scarbrough, K. Identification of woodland vernal pools with seasonal change PALSAR data for habitat conservation. Remote Sens. 2016, 8 , 490. [CrossRef]

28. Schnack, J.A. Why wetlands? Oecol. Bras. 2006, 10, 127-134. [CrossRef]

29. Leibowitz, S.G.; Wigington, P.J., Jr.; Schofield, K.A.; Alexander, L.C.; Vanderhoof, M.K.; Golden, H.E. Connectivity of streams and wetlands to downstream waters: An integrated systems framework. J. Am. Water Resour. Assoc. 2018, 54, 298-322. [CrossRef] [PubMed]

30. Brooks, R.T. A review of basin morphology and pool hydrology of isolated ponded wetlands: Implications for seasonal forest pools of the northeastern United States. Wetl. Ecol. Manag. 2005, 13, 335-348. [CrossRef]

31. Fellman, J.B.; Dogramaci, S.; Skrzypek, G.; Dodson, W.; Grierson, P.F. Hydrologic control of dissolved organic matter biogeochemistry in pools of a subtropical dryland river. Water Resour. Res. 2011, 47, W06501. [CrossRef]

32. Brooks, R.T.; Hayashi, M. Depth-area-volume and hydroperiod relationships of ephemeral (vernal) forest pools in southern New England. Wetlands 2002, 22, 247-255. [CrossRef]

33. Hamilton, S.K.; Bunn, S.E.; Thoms, M.C.; Marshall, J.C. Persistence of aquatic refugia between flow pulses in a dryland river system (Cooper Creek, Australia). Limnol. Oceanogr. 2005, 50, 743-754. [CrossRef]

34. Schofield, K.A.; Alexander, L.C.; Ridley, C.E.; Vanderhoof, M.K.; Fritz, K.M.; Autrey, B.C.; DeMeester, J.; Kepner, W.G.; Lane, C.R.; Leibowitz, S.; et al. Biota connect aquatic habitats throughout freshwater ecosystem mosaics. JAWRA 2018, 54, 372-399. [CrossRef]

35. Zeug, S.C.; Winemiller, K.O.; Tarim, S. Response of Brazos River oxbow fish assemblages to patterns of hydrologic connectivity and environmental variability. Trans. Am. Fish. Soc. 2005, 134, 1389-1399. [CrossRef]

36. Leopold, L.B.; Miller, J.P. Ephemeral Streams. Hydraulic Factors and Their Relation to the Drainage Net; U.S. Geological Survey Professional Paper 282-A; US Government Printing Office: Washington, DC, USA, 1956. Available online: https://pubs.usgs.gov/pp/0282a/report.pdf (accessed on 14 October 2020).

37. Dogramaci, S.; Firmani, G.; Hedley, P.; Skrzypek, G.; Grierson, P.F. Evaluating recharge to an ephemeral dryland stream using a hydraulic model and water, chloride and isotope mass balance. J. Hydrol. 2015, 521, 520-532. [CrossRef]

38. Rau, G.C.; Halloran, L.J.; Cuthbert, M.O.; Andersen, M.S.; Acworth, R.I.; Tellam, J.H. Characterising the dynamics of surface water-groundwater interactions in intermittent and ephemeral streams using streambed thermal signatures. Adv. Water Resour. 2017, 107, 354-369. [CrossRef]

39. Smakhtin, V.U. Low flow hydrology: A review. J. Hydrol. 2001, 240, 147-186. [CrossRef]

40. Gallart, F.; Llorens, P.; Latron, J.; Cid, N.; Rieradevall, M.; Prat, N. Validating alternative methodologies to estimate the regime of temporary rivers when flow data are unavailable. Sci. Total Environ. 2016, 565, 1001-1010. [CrossRef]

41. WMO (World Meteorological Organization). Manual on Stream Gauging. Volume I-Fieldwork; WMO-No. 1044; WMO: Geneva, Switzerland, 2010; 254p, Available online: http://www.wmo.int/pages/prog/hwrp/ publications/stream_gauging/1044_Vol_I_en.pdf (accessed on 14 October 2020).

42. Zimmer, M.A.; Kaiser, K.E.; Blaszczak, J.R.; Zipper, S.C.; Hammond, J.C.; Fritz, K.M.; Costigan, K.H.; Hosen, J.; Godsey, S.E.; Allen, G.H.; et al. Zero or not? Causes and consequences of zero-flow stream gage readings. WIRES Water 2020, e1436. [CrossRef] [PubMed] 
43. Puckridge, J.T.; Walker, K.F.; Costelloe, J.F. Hydrological persistence and the ecology of dryland rivers. Regul. Rivers Res. Manag. 2000, 16, 385-402. [CrossRef]

44. Callow, J.N.; Boggs, G. Studying reach-scale spatial hydrology in ungauged catchments. J. Hydrol. 2013, 496, 31-46. [CrossRef]

45. Fritz, K.M.; Johnson, B.R.; Walters, D.M. Field Operations Manual for Assessing the Hydrologic Permanence and Ecological Condition of Headwater Streams; EPA/600/ R-06/126; US Environmental Protection Agency, Office of Research and Development: Washington, DC, USA, 2006.

46. Sefton, C.E.; Parry, S.; England, J.; Angell, G. Visualising and quantifying the variability of hydrological state in intermittent rivers. Fundam. Appl. Limnol. Archiv Hydrobiol. 2019, 193, 21-38. [CrossRef]

47. Blasch, K.W.; Ferré, T.P.; Christensen, A.H.; Hoffmann, J.P. New field method to determine streamflow timing using electrical resistance sensors. Vadose Zone J. 2002, 1, 289-299. [CrossRef]

48. Gungle, B. Timing and Duration of Flow in Ephemeral Streams of the Sierra Vista Subwatershed of the Upper San Pedro Basin, Cochise County, Southeastern Arizona; U.S. Geological Survey Scientific Investigations, Report 2005-5190; US Geological Survey: Reston, VA, USA, 2006; 47p. [CrossRef]

49. Chapin, T.P.; Todd, A.S.; Zeigler, M.P. Robust, low-cost data loggers for stream temperature, flow intermittency, and relative conductivity monitoring. Water Resour. Res. 2014, 50, 6542-6548. [CrossRef]

50. Bhamjee, R.; Lindsay, J.B.; Cockburn, J. Monitoring ephemeral headwater streams: A paired-sensor approach. Hydrol. Process. 2016, 30, 888-898. [CrossRef]

51. Assendelft, R.S.; van Meerveld, H.J. A Low-Cost, multi-Sensor system to monitor temporary stream dynamics in mountainous headwater catchments. Sensors 2019, 19, 4645. [CrossRef]

52. Straka, M.; Polášek, M.; Syrovátka, V.; Stubbington, R.; Zahrádková, S.; Němejcová, D.; Šikulová, L.; Řezníčková, P.; Opatřilová, L.; Datry, T.; et al. Recognition of stream drying based on benthic macroinvertebrates: A new tool in Central Europe. Ecol. Indic. 2019, 106, 105486. [CrossRef]

53. Skrzypek, G.; Mydłowski, A.; Dogramaci, S.; Hedley, P.; Gibson, J.J.; Grierson, P.F. Estimation of evaporative loss based on the stable isotope composition of water using Hydrocalculator. J. Hydrol. 2015, 523, 781-789. [CrossRef]

54. Keller, E.A.; Melhorn, W.M. Rhythmic spacing and origin of pools and riffles. Geol. Soc. Am. Bull. 1978, 89, 723-730. [CrossRef]

55. Carling, P.A.; Orr, H.G. Morphology of riffle-pool sequences in the river Severn, England. Earth Surf. Process. 2000, 25, 369-384. [CrossRef]

56. Keller, E.A. Pools, riffles, and meanders: Discussion. Geol. Soc. Am. Bull. 1971, 82, 279-280. [CrossRef]

57. Richards, K.S. Channel width and the riffle-pool sequence. Geol. Soc. Am. Bull. 1976, 87, 883-890. [CrossRef]

58. Knighton, D. Fluvial Forms and Processes; Arnold: London, UK, 1984; 218p.

59. Thompson, D.M. Pool-Riffle sequences. Ref. Modul. Earth Syst. Environ. Sci. 2020. [CrossRef]

60. Ferguson, R.I. Understanding braiding processes in gravel-bed rivers: Progress and unsolved problems. Geol. Soc. Sp. Publ. 1993, 75, 73-87. [CrossRef]

61. Lisle, T.E.; Hilton, S. The volume of fine sediment in pools: An index of sediment supply in gravel-bed streams. J. Am. Water Resour. Assoc. 1992, 28, 371-383. [CrossRef]

62. Lisle, T.E. Using 'Residual Depths' to Monitor Pool Depths Independently of Discharge; U.S. Forest Service Research Note PSW-394; U.S. Department of Agriculture, Forest Service, Pacific Southwest Forest and Range Experiment Station: Berkeley, CA, USA, 1987.

63. Beesley, L. Environmental Stability: Its Role in Structuring Fish Communities and Life History Strategies in the Fortescue River, Western Australia. Ph.D. Thesis, The University of Western Australia, Perth, Australia, 2006.

64. Marimon, M. Effects of Flow Intermittence on Fish Fauna in Mediterranean-Climate Rivers. Master's Thesis, University of Barcelona, Barcelona, Spain, 2018. Available online: http://www.ub.edu/fem/docs/treballs/ TFM_Marc_Marimon.pdf (accessed on 14 October 2020).

65. Gómez, R.; Arce, M.I.; Baldwin, D.S.; Dahm, C.N. Water physicochemistry in intermittent rivers and ephemeral streams. In Intermittent Rivers and Ephemeral Streams: Ecology and Management; Datry, T., Bonada, N., Boulton, A.J., Eds.; Elsevier, Inc.: Cambridge, MA, USA, 2017; pp. 109-134. [CrossRef]

66. von Schiller, D.; Bernal, S.; Dahm, C.N.; Martí, E. Nutrient and Organic Matter Dynamics in Intermittent Rivers and Ephemeral Streams. In Intermittent Rivers and Ephemeral Streams: Ecology and Management; Datry, T., Bonada, N., Boulton, A.J., Eds.; Elsevier, Inc.: Cambridge, MA, USA, 2017; pp. 135-160. [CrossRef] 
67. Bestland, E.; George, A.; Green, G.; Olifent, V.; Mackay, D.; Whalen, M. Groundwater dependent pools in seasonal and permanent streams in the Clare Valley of South Australia. J. Hydrol. Reg. Stud. 2017, 9, $216-235$. [CrossRef]

68. Siebers, A.R.; Pettit, N.E.; Skrzypek, G.; Fellman, J.B.; Dogramaci, S.; Grierson, P.F. Alluvial ground water influences dissolved organic matter biogeochemistry of pools within intermittent dryland streams. Freshw. Biol. 2016, 61, 1228-1241. [CrossRef]

69. Larned, S.T.; Datry, T.; Arscott, D.B.; Tockner, K. Emerging concepts in temporary-river ecology. Freshw. Biol. 2010, 55, 717-738. [CrossRef]

70. Fisher, S.G.; Grimm, N.B.; Martí, E.; Holmes, R.M.; Jones, J.B., Jr. Material spiraling in stream corridors: A telescoping ecosystem model. Ecosystems 1998, 1, 19-34. [CrossRef]

71. Bernal, S.; von Schiller, D.; Sabater, F.; Martí, E. Hydrological extremes modulate nutrient dynamics in mediterranean climate streams across different spatial scales. Hydrobiologia 2013, 719, 31-42. [CrossRef]

72. Harjung, A.; Sabater, F.; Butturini, A. Hydrological connectivity drives dissolved organic matter processing in an intermittent stream. Limnologica 2018, 68, 71-81. [CrossRef]

73. Acuña, V.; Giorgi, A.; Muñoz, I.; Sabater, F.; Sabater, S. Meteorological and riparian influences on organic matter dynamics in a forested Mediterranean stream. J. N. Am. Benthol. Soc. 2007, 26, 54-69. [CrossRef]

74. Turner, L.; Erskine, W.D. Variability in the development, persistence and breakdown of thermal, oxygen and salt stratification on regulated rivers of southeastern Australia. River Res. Appl. 2005, 21, 151-168. [CrossRef]

75. Overton, I.C.; Colloff, M.J.; Doody, T.M.; Henderson, B.; Cuddy, S.M. Ecological Outcomes of Flow Regimes in the Murray-Darling Basin; Report prepared for the National Water Commission by CSIRO Water for a Healthy Country Flagship; CSIRO: Canberra, Australia, 2009; 422p. [CrossRef]

76. Gómez, R.; García, V.; Vidal-Abarca, R.; Suárez, L. Effect of intermittency on N spatial variability in an arid Mediterranean stream. J. N. Am. Benthol. Soc. 2009, 28, 572-583. [CrossRef]

77. Seaman, M.T.; Avenant, M.F.; Watson, M.; King, J.; Armour, J.; Barker, C.H.; Dollar, E.; Du Preez, P.J.; Hughes, D.; Rossouw, L.; et al. Developing a Method for Determining the Environmental Water Requirements for Non-Perennial Systems; Report Number: WRC TT459/10; Centre for Environmental Management University of the Free State: Bloemfontein, South Africa, 2009.

78. von Schiller, D.; Acuña, V.; Graeber, D.; Martí, E.; Ribot, M.; Sabater, S.; Timoner, X.; Tockner, K. Contraction, fragmentation and expansion dynamics determine nutrient availability in a Mediterranean forest stream. Aquat. Sci. 2011, 73, 485-497. [CrossRef]

79. Day, J.A.; Malan, H.L.; Malijani, E.; Abegunde, A.P. Water quality in non-perennial rivers. Water SA 2019, 45, 487-500. [CrossRef]

80. Zale, A.V.; Leslie, D.M., Jr.; Fisher, W.L.; Merrifield, S.G. The Physicochemistry, Flora, and Fauna of Intermittent Prairie Streams: A Review of the Literature; US Department of the Interior, Fish and Wildlife Service: Washington, DC, USA, 1989; Volume 89.

81. Williams, D.D. The Biology of Temporary Waters; Oxford University Press: Oxford, UK, 2006. [CrossRef]

82. Lillebø, A.I.; Morais, M.; Guilherme, P.; Fonseca, R.; Serafim, A.; Neves, R. Nutrient dynamics in Mediterranean temporary streams: A case study in Pardiela catchment (Degebe River, Portugal). Limnologica 2007, 37, 337-348. [CrossRef]

83. Burrows, R.M.; Rutlidge,H.; Bond, N.R.; Eberhard, S.M.; Auhl, A.; Andersen, M.S.; Valdez, D.G.; Kennard, M.J. High rates of organic carbon processing in the hyporheic zone of intermittent streams. Sci. Rep. 2017, 7, 13198. [CrossRef]

84. Fazi, S.; Vázquez, E.; Casamayor, E.O.; Amalfitano, S.; Butturini, A. Stream hydrological fragmentation drives bacterioplankton community composition. PLoS ONE 2013, 8, e64109. [CrossRef]

85. Sabater, S.; Timoner, X.; Borrego, C.; Acuña, V. Stream biofilm responses to flow intermittency: From cells to ecosystems. Front. Environ. Sci. 2016, 4, 14. [CrossRef]

86. Freixa, A.; Ejarque, E.; Crognale, S.; Amalfitano, S.; Fazi, S.; Butturini, A.; Romaní, A.M. Sediment microbial communities rely on different dissolved organic matter sources along a Mediterranean river continuum. Limnol. Oceanogr. 2016, 61, 1389-1405. [CrossRef]

87. Baker, M.A.; Dahm, C.N.; Valett, H.M. Anoxia, anaerobic metabolism, and biogeochemistry of the stream-water-ground-water interface. In Streams and Ground Waters; Jones, J.B., Mulholland, P.J., Eds.; Academic Press: San Diego, CA, USA, 2000; pp. 259-283. [CrossRef] 
88. Baldwin, D.S.; Rees, G.N.; Wilson, J.S.; Colloff, M.J.; Whitworth, K.L.; Pitman, T.L.; Wallace, T.A. Provisioning of bioavailable carbon between the wet and dry phases in a semi-arid floodplain. Oecologia 2013, 172, 539-550. [CrossRef]

89. Boulton, A.J.; Lake, P.S. Benthic organic matter and detritivorous macroinvertebrates in two intermittent streams in south-eastern Australia. Hydrobiologia 1992, 241, 107-118. [CrossRef]

90. Acuña, V.; Muñoz, I.; Giorgi, A.; Omella, M.; Sabater, F.; Sabater, S. Drought and postdrought recovery cycles in an intermittent Mediterranean stream: Structural and functional aspects. J. N. Am. Benthol. Soc. 2005, 24, 919-933. [CrossRef]

91. Romaní, A.M.; Amalfitano, S.; Artigas, J.; Fazi, S.; Sabater, S.; Timoner, X.; Ylla, I.; Zoppini, A. Microbial biofilm structure and organic matter use in mediterranean streams. Hydrobiologia 2013, 719, 43-58. [CrossRef]

92. Pattee, E.; Maamri, A.; Chergui, H. Leaf litter processing and its agents in a temporary Moroccan river. Int. Ver. Theor. Angew. Limnol. Verh. 2001, 27, 3054-3057. [CrossRef]

93. Schlief, J.; Mutz, M. Leaf decay processes during and after a supra-seasonal hydrological drought in a temperate lowland stream. Int. Rev. Hydrobiol. 2011, 96, 633-655. [CrossRef]

94. Abril, M.; Muñoz, I.; Menéndez, M. Heterogeneity in leaf litter decomposition in a temporary Mediterranean stream during flow fragmentation. Sci. Total Environ. 2016, 553, 330-339. [CrossRef] [PubMed]

95. Arias-Real, R.; Muñoz, I.; Gutierrez-Cánovas, C.; Granados, V.; Lopez-Laseras, P.; Menéndez, M. Subsurface zones in intermittent streams are hotspots of microbial decomposition during the non-flow period. Sci. Total Environ. 2020, 703, 135485. [CrossRef] [PubMed]

96. Canhoto, C.; Laranjeira, C. Leachates of Eucalyptus globulus in intermittent streams affect water parameters and invertebrates. Int. Rev. Hydrobiol. 2007, 92, 173-182. [CrossRef]

97. Casas-Ruiz, J.P.; Tittel, J.; von Schiller, D.; Catalán, N.; Obrador, B.; Gómez-Gener, L.; Zwirnmann, E.; Sabater, S.; Marcé, R. Drought-induced discontinuities in the source and degradation of dissolved organic matter in a Mediterranean river. Biogeochemistry 2016, 127, 125-139. [CrossRef]

98. Dahm, V.; Hering, D.; Nemitz, D.; Graf, W.; Schmidt-Kloiber, A.; Leitner, P.; Melcher, A.; Feld, C.K. Effects of physico-chemistry, land use and hydromorphology on three riverine organism groups: A comparative analysis with monitoring data from Germany and Austria. Hydrobiologia 2013, 704, 389-415. [CrossRef]

99. Vazquez, E.; Amalfitano, S.; Fazi, S.; Butturini, A. Dissolved organic matter composition in a fragmented Mediterranean fluvial system under severe drought conditions. Biogeochemistry 2011, 102, 59-72. [CrossRef]

100. von Schiller, D.; Graeber, D.; Ribot, M.; Timoner, X.; Acuña, V.; Martí, E.; Sabater, S.; Tockner, K. Hydrological transitions drive dissolved organic matter quantity and composition in a temporary Mediterranean stream. Biogeochemistry 2015, 123, 429-446. [CrossRef]

101. Granados, V.; Gutiérrez-Cánovas, C.; Arias-Real, R.; Obrador, B.; Harjung, A.; Butturini, A. The interruption of longitudinal hydrological connectivity causes delayed responses in dissolved organic matter. Sci. Total Environ. 2020, 713, 136619. [CrossRef]

102. Catalán, N.; Casas-Ruiz, J.P.; von Schiller, D.; Proia, L.; Obrador, B.; Zwirnmann, E.; Marcé, R. Biodegradation kinetics of dissolved organic matter chromatographic fractions in an intermittent river. J. Geophys. Res. Biogeosci. 2017, 122. [CrossRef]

103. Gómez-Gener, L.; Obrador, B.; von Schiller, D.; Marcé, R.; Casas-Ruiz, J.P.; Proia, L.; Acuña, V.; Catalán, N.; Muñoz, I.; Koschorreck, M. Hot spots for carbon emissions from Mediterranean fluvial networks during summer drought. Biogeochemistry 2015, 125, 409-426. [CrossRef]

104. Romaní, A.M.; Chauvet, E.; Febria, C.; Mora-Gómez, J.; Risse-Buhl, U.; Timoner, X.; Weitere, M.; Zeglin, L. The biota of intermittent rivers and ephemeral streams: Prokaryotes, fungi, and protozoans. In Intermittent Rivers and Ephemeral Streams: Ecology and Management; Datry, T., Bonada, N., Boulton, A.J., Eds.; Elsevier, Inc.: Cambridge, MA, USA, 2017; pp. 161-188. [CrossRef]

105. Sabater, S.; Timoner, X.; Bornette, G.; De Wilde, M.; Stromberg, J.C.; Stella, J.C. The biota of intermittent rivers and ephemeral streams: Algae and vascular plants. In Intermittent Rivers and Ephemeral Streams: Ecology and Management; Datry, T., Bonada, N., Boulton, A.J., Eds.; Elsevier, Inc.: Cambridge, MA, USA, 2017; pp. 189-216. [CrossRef]

106. Stubbington, R.; Bogan, M.T.; Bonada, N.; Boulton, A.J.; Datry, T.; Leigh, C.; Vander Vorste, R. The biota of intermittent rivers and ephemeral streams: Aquatic invertebrates. In Intermittent Rivers and Ephemeral Streams: Ecology and Management; Datry, T., Bonada, N., Boulton, A.J., Eds.; Elsevier, Inc.: Cambridge, MA, USA, 2017; pp. 217-243. [CrossRef] 
107. Kerezsy, A.; Gido, K.; Magalhaes, M.F.; Skelton, P.H. The biota of intermittent rivers and ephemeral streams: Fishes. In Intermittent Rivers and Ephemeral Streams: Ecology and Management; Datry, T., Bonada, N., Boulton, A.J., Eds.; Elsevier, Inc.: Cambridge, MA, USA, 2017; pp. 273-298. [CrossRef]

108. Mora-Gómez, J.; Elosegi, A.; Duarte, S.; Cássio, F.; Pascoal, C.; Romaní, A.M. Differences in the sensitivity of fungi and bacteria to season and invertebrates affect leaf litter decomposition in a Mediterranean stream. FEMS Microbiol. Ecol. 2016, 92. [CrossRef] [PubMed]

109. Drummond, L.R.; McIntosh, A.R.; Larned, S.T. Invertebrate community dynamics and insect emergence in response to pool drying in a temporary river. Freshw. Biol. 2015, 60, 1596-1612. [CrossRef]

110. Aparicio, E.; Sostoa, A. Pattern of movements of adult Barbus haasi in a small Mediterranean stream. J. Fish Biol. 1999, 55, 1086-1095. [CrossRef]

111. Hill, M.J.; Milner, V.S. Ponding in intermittent streams: A refuge for lotic taxa and a habitat for newly colonising taxa? Sci. Total Environ. 2018, 628-629, 1308-1316. [CrossRef]

112. Van Leeuwen, C.H.; van der Velde, G. Prerequisites for flying snails: External transport potential of aquatic snails by waterbirds. Freshw. Sci. 2012, 31, 963-972. [CrossRef]

113. Arthington, A.H.; Balcombe, S.R. Extreme flow variability and the 'boom and bust' ecology of fish in arid-zone floodplain rivers: A case history with implications for environmental flows, conservation and management. Ecohydrology 2011, 4, 708-720. [CrossRef]

114. Ribera, I.; Foster, G.N.; Vogler, A.P. Does habitat use explain large scale species richness patterns of aquatic beetles in Europe? Ecography 2003, 26, 145-152. [CrossRef]

115. Bogan, M.T.; Chester, E.T.; Datry, T.; Murphy, A.L.; Robson, B.J.; Ruhí, A.; Stubbington, R.; Whitney, J.E. Resistance, resilience, and community recovery in intermittent rivers and ephemeral streams. In Intermittent Rivers and Ephemeral Streams: Ecology and Management; Datry, T., Bonada, N., Boulton, A.J., Eds.; Elsevier, Inc.: Cambridge, MA, USA, 2017; pp. 349-376. [CrossRef]

116. Bazzanti, M.; Seminara, M.; Baldoni, S. Chironomids (Diptera: Chironomidae) from three temporary ponds of different wet phase duration in central Italy. J. Freshw. Ecol. 1997, 12, 89-99. [CrossRef]

117. Woelfle-Erskine, C.; Larsen, L.G.; Carlson, S.M. Abiotic habitat thresholds for salmonid over-summer survival in intermittent streams. Ecosphere 2017, 8, e01645. [CrossRef]

118. Anusa, A.; Ndagurwa, H.G.T.; Magadza, C.H.D. The influence of pool size on species diversity and water chemistry in temporary rock pools on Domboshawa Mountain, northern Zimbawe. Afr. J. Aquat. Sci. 2012, 37, 89-99. [CrossRef]

119. Angermeier, P.L.; Schlosser, I.J. Species-area relationship for stream fishes. Ecology 1989, 70, 1450-1462. [CrossRef]

120. Taylor, C.M. Fish species richness and incidence patterns in isolated and connected stream pools: Effects of pool volume and spatial position. Oecologia 1997, 110, 560-566. [CrossRef] [PubMed]

121. Arthington, A.H.; Olden, J.D.; Balcombe, S.R.; Thoms, M.C. Multi-scale environmental factors explain fish losses and refuge quality in drying waterholes of Cooper Creek, an Australian arid-zone river. Mar. Freshw. Res. 2010, 61, 842-856. [CrossRef]

122. García-Roger, E.M.; Sánchez-Montoya, M.M.; Gómez, R.; Suárez, M.L.; Vidal-Abarca, M.R.; Latron, J.; Rieradevall, M.; Prat, N. Do seasonal changes in habitat features influence aquatic macroinvertebrate assemblages in perennial versus temporary Mediterranean streams? Aquat. Sci. 2011, 73, 567-579. [CrossRef]

123. Morey, S.R. Pool duration influences age and body mass at metamorphosis in the western spadefoot toad: Implications for vernal pool conservation. In Ecology, Conservation, and Management of Vernal Pool Ecosystem, Proceedings from a 1996 Conference, Sacramento, CA, USA, 1996; Witham, C.W., Bauder, E.T., Belk, D., Ferren, W.R., Jr., Ornduff, R., Eds.; California Native Plant Society: Sacramento, CA, USA, 1998; pp. 86-91.

124. Bonada, N.; Carlson, S.M.; Datry, T.; Finn, D.S.; Leigh, C.; Lytle, D.A.; Monaghan, M.T.; Tedesco, P.A. Genetic, evolutionary, and biogeographical processes in intermittent rivers and ephemeral streams. In Intermittent Rivers and Ephemeral Streams: Ecology and Management; Datry, T., Bonada, N., Boulton, A.J., Eds.; Elsevier, Inc.: Cambridge, MA, USA, 2017; pp. 405-431. [CrossRef]

125. McIntosh, A.R.; Leigh, C.; Boersma, K.S.; McHugh, P.A.; Febria, C.; García-Berthou, E. Food webs and trophic interactions in intermittent rivers and ephemeral streams. In Intermittent Rivers and Ephemeral Streams: Ecology and Management; Datry, T., Bonada, N., Boulton, A.J., Eds.; Elsevier, Inc.: Cambridge, MA, USA, 2017; pp. 323-347. [CrossRef] 
126. DuBose, T.P.; Ashford, K.; Vaughn, C.C. Freshwater mussels increase survival of largemouth bass (Micropterus salmoides) in drying pools. Ecol. Freshw. Fish 2019, 29, 220-229. [CrossRef]

127. Williams, L.R.; Taylor, C.M.; Warren, M.L., Jr. Influence of fish predation on assemblage structure of macroinvertebrates in an intermittent stream. Trans. Am. Fish. Soc. 2003, 132, 120-130. [CrossRef]

128. Driver, L.J.; Hoeinghaus, D.J. Fish metacommunity responses to experimental drought are determined by habitat heterogeneity and connectivity. Freshw. Biol. 2016, 61, 533-548. [CrossRef]

129. Vanschoenwinkel, B.; Hulsmans, A.; De Roeck, E.; De Vries, C.; Seaman, M.; Brendonck, L. Community structure in temporary freshwater pools: Disentangling the effects of habitat size and hydroregime. Freshw. Biol. 2009, 54, 1487-1500. [CrossRef]

130. Tonkin, J.D.; Stoll, S.; Sundermann, A.; Haase, P. Dispersal distance and the pool of taxa, but not barriers, determine the colonisation of restored river reaches by benthic invertebrates. Freshw. Biol. 2014, 59, 1843-1855. [CrossRef]

131. Heino, J.; Melo, A.S.; Siqueira, T.; Soininen, J.; Valanko, S.; Bini, L.M. Metacommunity organisation, spatial extent and dispersal in aquatic systems: Patterns, processes and prospects. Freshw. Biol. 2015, 60, 845-869. [CrossRef]

132. Chase, J.M. Drought mediates the importance of stochastic community assembly. Proc. Natl. Acad. Sci. USA 2007, 104, 17430-17434. [CrossRef]

133. Cañedo-Argüelles, M.; Bogan, M.T.; Lytle, D.A.; Prat, N. Are Chironomidae (Diptera) good indicators of water scarcity? Dryland streams as a case study. Ecol. Indic. 2016, 71, 155-162. [CrossRef]

134. Cañedo-Argüelles, M.; Boersma, K.S.; Bogan, M.T.; Olden, J.D.; Phillipsen, I.; Schriever, T.A.; Lytle, D.A. Dispersal strength determines meta-community structure in a dendritic riverine network. J. Biogeogr. 2015, 42, 778-790. [CrossRef]

135. Phillipsen, I.C.; Lytle, D.A. Aquatic insects in a sea of desert: Population genetic structure is shaped by limited dispersal in a naturally fragmented landscape. Ecography 2013, 36, 731-743. [CrossRef]

136. Tornés, E.; Ruhí, A. Flow intermittency decreases nestedness and specialisation of diatom communities in Mediterranean rivers. Freshw. Biol. 2013, 58, 2555-2566. [CrossRef]

137. Ruhí, A.; Datry, T.; Sabo, J.L. Interpreting beta-diversity components over time to conserve metacommunities in highly dynamic ecosystems. Conserv. Biol. 2017, 31, 1459-1468. [CrossRef]

138. Rogosch, J.S.; Olden, J.D. Dynamic contributions of intermittent and perennial streams to fish beta diversity in dryland rivers. J. Biogeogr. 2019, 46, 2311-2322. [CrossRef]

139. Ebert, T.A.; Balko, M.L. Temporary pools as islands in space and in time: The biota of vernal pools in San Diego, Southern California, USA. Arch. Hydrobiol. 1987, 110, 101-123.

140. Boix, D.; Sala, J.; Moreno-Amich, R. The faunal composition of Espolla pond (NE Iberian peninsula): The neglected biodiversity of temporary waters. Wetlands 2001, 21, 577-592. [CrossRef]

141. Lumbreras, A.; Marques, J.; Belo, A.F.; Cristo, M.; Fernandes, M.; Galioto, D.; Machado, M.; Mira, A.; Sá-Sousa, L.G.; Pinto-Cruz, C. Assessing the conservation status of Mediterranean temporary ponds using biodiversity: A new tool for practitioners. Hydrobiologia 2016, 782, 187-199. [CrossRef]

142. Rodríguez-Lozano, P.; Woelfle-Erskine, C.; Bogan, M.T.; Carlson, S.M. Are non-perennial rivers considered as valuable and worthy of conservation as perennial rivers? Sustainability 2020, 12, 5782. [CrossRef]

143. Hermoso, V.; Ward, D.P.; Kennard, M.J. Prioritizing refugia for freshwater biodiversity conservation in highly seasonal ecosystems. Divers. Distrib. 2013, 19, 1031-1042. [CrossRef]

144. Nicolet, P.; Biggs, J.; Fox, G.; Hodson, M.J.; Reynolds, C.; Whitfield, M.; Williams, P. The wetland plant and macroinvertebrate assemblages of temporary ponds in England and Wales. Biol. Conserv. 2004, 120, 261-278. [CrossRef]

145. Lukács, B.A.; Sramkó, G.; Molnár, A. Plant diversity and conservation value of continental temporary pools. Biol. Conserv. 2013, 158, 393-400. [CrossRef]

146. IPBES. Global Assessment Report on Biodiversity and Ecosystem Services of the Intergovernmental Science-Policy Platform on Biodiversity and Ecosystem Services; Brondizio, E.S., Settele, J., Díaz, S., Ngo, H.T., Eds.; IPBES Secretariat: Bonn, Germany, 2019.

147. Rhazi, L.; Grillas, P.; Saber, E.R.; Rhazi, M.; Brendonck, L.; Waterkeyn, A. Vegetation of Mediterranean temporary pools: A fading jewel? Hydrobiologia 2012, 689, 23-36. [CrossRef]

148. Van den Broeck, M.; Waterkeyn, A.; Rhazi, L.; Grillas, P.; Brendonck, L. Assessing the ecological integrity of endorheic wetlands, with focus on Mediterranean temporary ponds. Ecol. Indic. 2015, 54, 1-11. [CrossRef] 
149. Biggs, J.; Von Fumetti, S.; Kelly-Quinn, M. The importance of small waterbodies for biodiversity and ecosystem services: Implications for policy makers. Hydrobiologia 2017, 793, 3-39. [CrossRef]

150. Hill, M.J.; Hassall, C.; Oertli, B.; Fahrig, L.; Robson, B.J.; Biggs, J.; Samways, M.J.; Usio, N.; Takamura, N.; Krishnaswamy, J.; et al. New policy directions for global pond conservation. Conserv. Lett. 2018, 11, e12447. [CrossRef]

151. Céréghino, R.; Biggs, J.; Oertli, B.; Declerck, S. The ecology of European ponds: Defining the characteristics of a neglected freshwater habitat. Hydrobiologia 2008, 597, 1-6. [CrossRef]

152. Hermoso, V.; Cattarino, L.; Kennard, M.J.; Watts, M.; Linke, S. Catchment zoning for freshwater conservation: Refining plans to enhance action on the ground. J. Appl. Ecol. 2015, 52, 940-949. [CrossRef]

153. Soria, M.; Gutiérrez-Cánovas, C.; Bonada, N.; Acosta, R.; Rodríguez-Lozano, P.; Fortuño, P.; Burgazzi, G.; Vinyoles, D.; Gallart, F.; Latron, J.; et al. Natural disturbances can produce misleading bioassessment results: Identifying metrics to detect anthropogenic impacts in intermittent rivers. J. Appl. Ecol. 2020, 57, 283-295. [CrossRef]

154. Cid, N.; Bonada, N.; Carlson, S.; Grantham, T.E.; Gasith, A.; Resh, V.H. High variability is a defining component of Mediterranean-climate rivers and their biota. Water 2017, 9, 52. [CrossRef]

155. Fritz, K.; Cid, N.; Autrey, B. Governance, legislation, and protection of intermittent rivers and ephemeral streams. In Intermittent Rivers and Ephemeral Streams: Ecology and Management; Datry, T., Bonada, N., Boulton, A.J., Eds.; Elsevier, Inc.: Cambridge, MA, USA, 2017; pp. 477-507. [CrossRef]

156. Stubbington, R.; Chadd, R.; Cid, N.; Csabai, Z.; Milisa, M.; Morais, M.; Munné, A.; Paril, P.; Pesic, V.; Tziortzis, I.; et al. Biomonitoring of intermittent rivers and ephemeral streams in Europe: Current practice and priorities to enhance ecological status assessments. Sci. Total Environ. 2018, 618, 1096-1113. [CrossRef] [PubMed]

157. Cid, N.; Bonada, N.; Heino, J.; Cañedo-Argüelles, M.; Crabot, J.; Sarremejane, R.; Soininen, J.; Stubbington, R.; Datry, T. A metacommunity approach to improve biological assessments in highly dynamic freshwater ecosystems. BioScience 2020, 70, 427-438. [CrossRef] [PubMed]

158. Pires, D.F.; Beja, P.; Magalhães, M.F. Out of pools: Movement patterns of mediterranean stream fish in relation to dry season refugia. River Res. Appl. 2014, 30, 1269-1280. [CrossRef]

159. Mesnage, V.; Bonneville, S.; Laignel, B.; Lefebvre, D.; Dupont, J.P.; Mikes, D. Filling of a wetland (Seine estuary, France): Natural eutrophication or anthropogenic process? A sedimentological and geochemical study of wetland organic sediments. Hydrobiologia 2002, 475/476, 423-435. [CrossRef]

160. Sánchez-Carrillo, S.; Angeler, D.G.; Álvarez-Cobelas, M.; Sánchez-Andrés, R. Freshwater wetland eutrophication. In Eutrophication: Causes, Consequences and Control; Ansari, A., Singh Gill, S., Lanza, G., Rast, W., Eds.; Springer: Dordrecht, The Netherlands, 2010; pp. 195-210. [CrossRef]

161. Costelloe, J.F.; Western, A.W.; Irvine, E.C. Development of hypersaline groundwater in alluvial aquifers of ephemeral rivers. In MODSIM 2007: International Congress on Modelling and Simulation; Oxley, L., Kulasiri, D., Eds.; Modelling and Simulation Society of Australia and New Zealand: Christchurch, New Zealand, 2007; pp. 1416-1422.

162. Luthy, R.G.; Sedlak, D.L.; Plumlee, M.H.; Austin, D.; Resh, V.H. Wastewater-effluent-dominated streams as ecosystem-management tools in a drier climate. Front. Ecol. Environ. 2015, 13, 477-485. [CrossRef]

163. Poff, N.L.; Richter, B.D.; Arthington, A.H.; Bunn, S.E.; Naiman, R.J.; Kendy, E.; Acreman, M.; Apse, C.; Bledsoe, B.P.; Freeman, M.C.; et al. The ecological limits of hydrologic alteration (ELOHA): A new framework for developing regional environmental flow standards. Freshw. Biol. 2010, 55, 147-170. [CrossRef]

164. Suárez-Alonso, M.L.; Vidal-Abarca, M.R. Aplicación del índice de calidad del bosque de ribera, QBR, a los cauces fluviales de la cuenca del río Segura. Tecnol. Agua 2000, 201, 33-45.

165. Sala, J.; Gascón, S.; Boix, D.; Gesti, J.; Quintana, X. Proposal of a rapid methodology to assess the conservation status of Mediterranean wetlands and its application in Catalunya (NE Iberian peninsula). Arch. Sci. 2004, 57, 141-152.

166. Quintana, X.D.; Cañedo-Argüelles, M.; Nebra, A.; Gascón, S.; Rieradevall, M.; Caiola, N.; Sala, J.; Ibàñez, C.; Sánchez-Millaruelo, N.; Boix, D. New tools to analyse the ecological status of Mediterranean wetlands and shallow lakes. In Experiences from Surface Water Quality Monitoring; Munné, A., Ginebreda, A., Prat, N., Eds.; Springer: Cham, Switzerland, 2015; pp. 171-199. [CrossRef]

167. Angeler, D.G.; García, G. Using emergence from soil propagule banks as indicators of ecological integrity in wetlands: Advantages and limitations. J. N. Am. Benthol. Soc. 2005, 24, 740-752. [CrossRef] 
168. Hajibabaei, M.; Shokralla, S.; Zhou, X.; Singer, G.; Baird, D.J. Environmental barcoding: A next-generation sequencing approach for biomonitoring applications using river benthos. PLOS ONE 2011, 6, e17497. [CrossRef] [PubMed]

169. Elbrecht, V.; Vamos, E.E.; Meissner, K.; Aroviita, J.; Leese, F. Assessing strengths and weaknesses of DNA metabarcoding-based macroinvertebrate identification for routine stream monitoring. Methods Ecol. Evol. 2017, 8, 1265-1275. [CrossRef]

170. Harper, L.R.; Lawson Handley, L.; Carpenter, A.I.; Ghazali, M.; Di Muri, C.; Macgregor, C.J.; Logan, T.W.; Law, A.; Breithaupt, T.; Read, D.S.; et al. Environmental DNA (eDNA) metabarcoding of pond water as a tool to survey conservation and management priority mammals. Biol. Conserv. 2019, 238, 108225. [CrossRef]

171. Jerde, C.L.; Wilson, E.A.; Dressler, T.L. Measuring global fish species richness with eDNA metabarcoding. Mol. Ecol. Resour. 2019, 19, 19-22. [CrossRef]

172. Furlan, E.M.; Davis, J.; Duncan, R.P. Identifying error and accurately interpreting environmental DNA metabarcoding results: A case study to detect vertebrates at arid zone waterholes. Mol. Ecol. Resour. 2020, 20, 1259-1276. [CrossRef]

Publisher's Note: MDPI stays neutral with regard to jurisdictional claims in published maps and institutional affiliations.

(C) 2020 by the authors. Licensee MDPI, Basel, Switzerland. This article is an open access article distributed under the terms and conditions of the Creative Commons Attribution (CC BY) license (http://creativecommons.org/licenses/by/4.0/). 